\title{
Long-Term Variations of Air Quality Influenced by Surface Ozone in a Coastal Site in India: Association with Synoptic Meteorological Conditions with Model Simulations
}

\author{
Resmi C T ${ }^{1}$, Nishanth $T^{2} \oplus$, Satheesh Kumar $M K^{3}$, Balachandramohan $M^{1}$ and \\ Valsaraj K T ${ }^{4, *}$ (D) \\ 1 Department of Physics, Erode Arts and Science College, Erode, Tamil Nadu-638009, India; \\ ctresmi816@gmail.com (R.C.T.); balamohan2006@gmail.com (B.M.) \\ 2 Department of Physics, Sree Krishna College Guruvayur, Kerala 680102, India; nisthu.t@gmail.com \\ 3 Department of Atomic and Molecular Physics, MAHE, Manipal, Karnataka 576104, India; \\ drmksatheesh@gmail.com \\ 4 Cain Department of Chemical Engineering, Louisiana State University, Baton Rouge, LA 70803, USA \\ * Correspondence: valsaraj@lsu.edu
}

Received: 25 December 2019; Accepted: 7 February 2020; Published: 12 February 2020

\begin{abstract}
Atmospheric ozone $\left(\mathrm{O}_{3}\right)$ in the surface level plays a central role in determining air quality and atmospheric oxidizing capacity. In this paper, we review our comprehensive results of simultaneous measurements of surface ozone $\left(\mathrm{O}_{3}\right)$ and its precursor gas (NOx) and weather parameters that were carried out continuously for a span of six years (January 2013-December 2018) at a typical rural coastal site, Kannur $\left(11.9^{\circ} \mathrm{N}, 75.4^{\circ} \mathrm{E}\right)$ in South India. Surface $\mathrm{O}_{3}$ concentration reached its maximum during daytime hours and minimum during the night time. The influence of solar radiation and water content on variations of $\mathrm{O}_{3}$ are discussed. A Multi-Layer Perceptron (MLP) artificial neural network technique has been used to understand the effect of atmospheric temperature on the increase in $\mathrm{O}_{3}$ over the past six years. This has been found that temperature has been a major contributor to the increase in $\mathrm{O}_{3}$ levels over the years. The National Centre for Atmospheric Research- Master Mechanism (NCAR-MM) Photochemical box model study was conducted to validate the variations of $\mathrm{O}_{3}$ in different seasons and years, and the results were shown to be in good agreement with observed trends.
\end{abstract}

Keywords: surface $\mathrm{O}_{3}$; precursor gases; Kannur; model simulation

\section{Introduction}

Pollution refers to the changes in atmospheric air quality caused by natural or human intervention [1]. A report by the World Health Organization (WHO) shows that air pollution is on the rise in developing countries [2]. According to the study report by the India State-Level Disease Burden Initiative Air Pollution Collaborators [3], air pollution is the fifth most common cause of death in India, and every year, over 26 million people in India receive treatment for air pollution-related diseases. Pollutants due to trace gases, particulate matter, and volatile organic compounds harm human health as well as the ecosystems [4,5].

Being an important pollutant in the lower atmosphere, inhaling ozone $\left(\mathrm{O}_{3}\right)$ leads to serious health problems, including reduced lung function and respiratory problems [6,7]. The two main causes of $\mathrm{O}_{3}$ showing up on the Earth's surface are the photochemical reactions of precursor gases (Carbon Monoxide, Methane, Non-Methane Hydro Carbons and Volatile Organic Compounds) in the presence 
of Nitrogen Oxide (NOx) and the inflow from the stratosphere. The amount of precursor gases emitted by human activities from rural and urban areas have a significant effect on $\mathrm{O}_{3}$ variations [8-10]. Moreover, $\mathrm{O}_{3}$ also acts as an active greenhouse gas by which it can modulate climate change through a positive radiative forcing [11]. $\mathrm{O}_{3}$ in the troposphere has increased approximately two-fold compared to pre-industrial years $[12,13]$. In addition to higher emissions of its precursors due to anthropogenic activities, atmospheric dynamics has a central role in controlling the concentrations of $\mathrm{O}_{3}$ in the troposphere [14-17]. Likewise, water vapor in the lower atmosphere, surface air temperature, and climatological factors also play a critical role in the spatial and temporal variations of surface $\mathrm{O}_{3}$ [18-20].

$\mathrm{NOx}\left(=\mathrm{NO}+\mathrm{NO}_{2}\right)$ is a prominent species found in the atmosphere, and it plays an important role in atmospheric $\mathrm{O}_{3}$ chemistry. In the stratosphere, it acts as a catalyst for $\mathrm{O}_{3}$ depletion and on the terrestrial level as important precursor of $\mathrm{O}_{3}$ formation [21-24]. In a rich $\mathrm{NO}_{2}$ environment, $\mathrm{O}_{3}$ is produced photochemically due to the acceleration of peroxy radicals formed by the oxidation of trace compounds, whereas in a high $\mathrm{NO}$ environment, the concentrations $\mathrm{O}_{3}$ is destroyed [25-28]. Changes in local weather conditions can greatly affect the surface $\mathrm{O}_{3}$ concentrations [29-32]. Therefore, analyzing the long-term variations in weather change that occur at a particular location is very useful for understanding the concentration of surface $\mathrm{O}_{3}$ concentrations [33-38]. Many studies [39-55] on the variations of $\mathrm{O}_{3}$ and its precursor gases revealed that higher surface $\mathrm{O}_{3}$ concentrations were observed in summer/autumn seasons and lower concentrations were observed during monsoon season.

Photochemical models are essential for assessing and studying the dynamics of an atmospheric trace gases and dust particles at a particular location [56-58]. Many groups [59-64] have used the NCAR-MM model to study in detail the photochemical reaction of trace gas in the terrestrial atmosphere for better understanding, and the model simulations were consistent with their observations.

Kannur, a heritage land in Kerala state that is reminiscent of the waves is growing rapidly. Unlike yesterday, each footprint takes villages and towns to new times. A part of it is a long stretch of beach and coconut plantations with greenery on more than half of the land; on the other side is the Western Ghats, which has grown into a magnificent place. There are many who set sail for the coast in the cool breeze of the Arabian Sea. The sky of the Arabian Sea, with its everlasting sunsets, attracts a large number of people to this gaze. The place is very popular during the holiday season, as it is easily accessible from the city. Even the smallest pollutants in the atmosphere of the Kannur can greatly affect the air quality of the place. Over the west coast of India, only few surface measurements of $\mathrm{O}_{3}$ are available. In view of this, an Atmospheric Chemistry-Transport and Modelling (AT-CTM) project was started under the Indian Space Research Organisation's Geosphere Biosphere Program (ISRO-GBP) for the continuous observations of surface $\mathrm{O}_{3}$ and its precursor gases from 2010 in Kannur, a coastal site in India.

Here, we describe a detailed review report on the changes observed in surface $\mathrm{O}_{3}, \mathrm{NOx}$ concentrations over the past six years at Kannur. We first investigated the influence of solar radiation and water content on the distribution of seasonal and diurnal variation of $\mathrm{O}_{3}$ and NOx. The relationship observed between weather parameters and $\mathrm{O}_{3}$ over the past six years is also described here. Further, Multi-Layer Perceptron (MLP) artificial neural network method is employed to investigate the effect of air temperature on the $\mathrm{O}_{3}$ concentration over the observational site. In addition to these, the measured variation of $\mathrm{O}_{3}$ is analyzed by using the NCAR-Master Mechanism Photochemical box model.

\section{Experimental Method}

\subsection{Observational Site and Measurement Techniques}

The observational site at Kannur is shown in Figure 1. Measurements of the concentrations of $\mathrm{O}_{3}$ and NOx originally started in December 2009 at Kannur University Campus (KUC); however, complete sets of data was obtained during the years January 2013 through December 2018 and are presented in this review. The measurement site is rural with limited industrial activities and is an ideal place to look at a growing semi-urban environment in India. The measurements of surface $\mathrm{O}_{3}$ 
( 5 min interval) were made using a continuous $\mathrm{O}_{3}$ analyzer (Model O342M) with a detection limit of 0.4 ppbv. Its measurement principle is based on $\mathrm{O}_{3}$ detection by direct absorption in UV light. The $\mathrm{O}_{3}$ absorption spectrum is intense in the 250 and $270 \mathrm{~nm}$ wavelength range. Thus, it corresponds to the maximum range of $\mathrm{O}_{3}$ absorption at $255 \mathrm{~nm}$. $\mathrm{NO}$ and $\mathrm{NO}_{2}$ were monitored with the aid of a nitrogen monoxide and nitrogen dioxide analyzer (Model AC32M) specific to low concentrations in the ambient air with a detection limit of 0.4 ppbv. Its measurement principle is based on the NO chemiluminescence in the presence of highly oxidizing $\mathrm{O}_{3}$ molecules. The $\mathrm{NO}$ in the ambient air is oxidized by $\mathrm{O}_{3}$ to form excited $\mathrm{NO}_{2}$ molecules. The concentrations of $\mathrm{NO}$ and $\mathrm{NO}_{2}$ were measured based on the spectrum of the radiation emitted by $\mathrm{NO}_{2}$ molecules at the excited level. More details about the observational site and the ground-based gas analyzers (Environment SA, France) used for this study were already reported by us earlier $[59,65]$. The weather parameters at the observational site was retrieved from the local automatic weather station established by the ISRO.

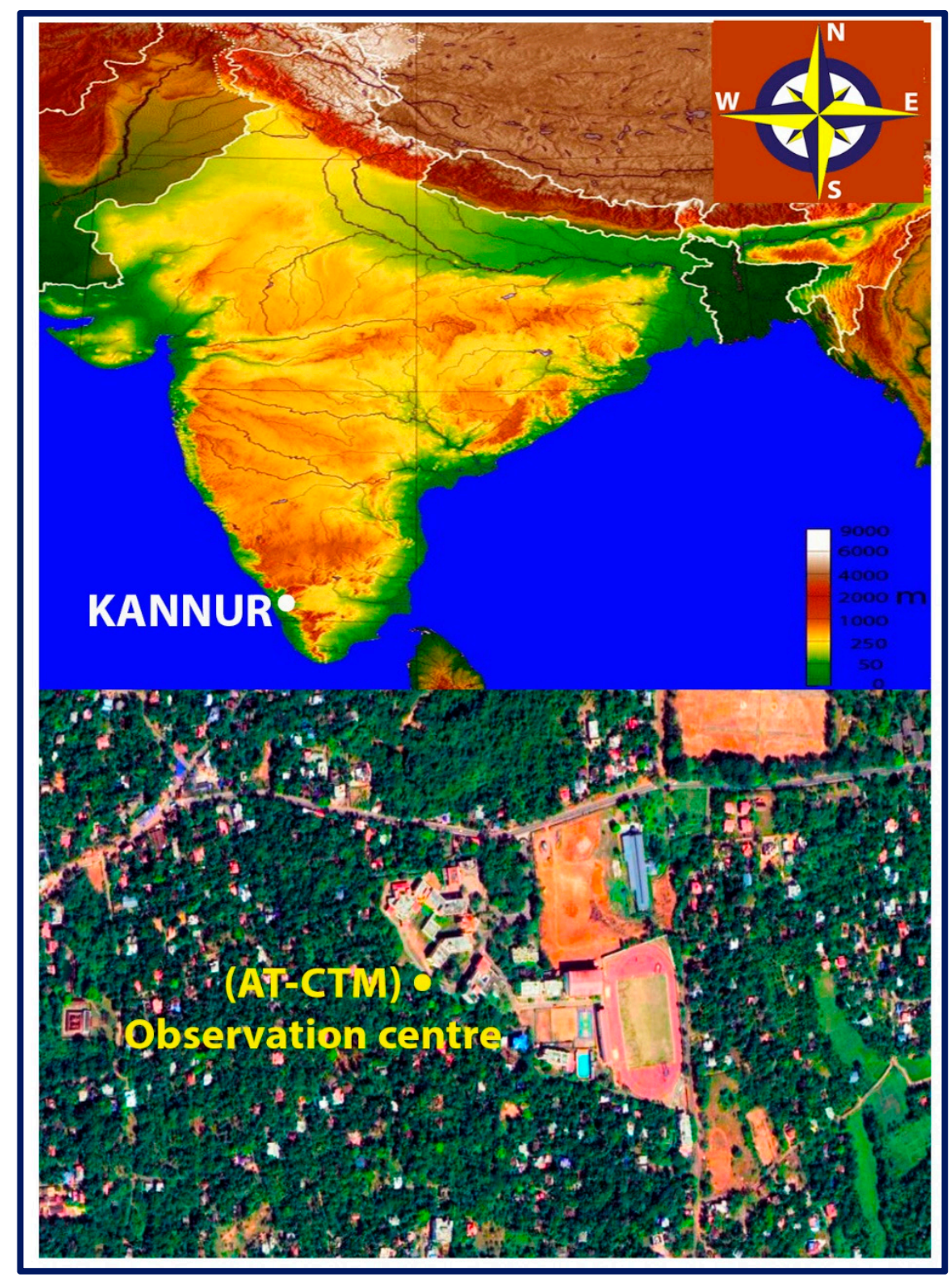

Figure 1. Geographical location of observational site at Kannur. 


\subsection{Artificial Neural Network}

To study the impact of air temperature on the variation of surface $\mathrm{O}_{3}$ over the observational site, an artificial neural network (ANN) method was used, and it is designed using air temperature as the sole varying input parameter. ANN are considered capable of modeling complex nonlinear processes [66-68]. A simple Multi-Layer Perceptron (MLP) model that is extensively used for regression analysis and time series autoregressive analysis comes under the category of feed-forward neural network (FFNN), which was employed here for the model simulations. The structure of the network consist of three layers-namely the input, hidden, and output layer-and the two nodes of each layer are interconnected, and the number of nodes in each hidden layer depends on the input parameters. More details of the network model are described elsewhere [68,69].

\section{Results and Discussions}

\subsection{Influence of Solar Radiation and Water Vapor on $\mathrm{O}_{3}$ and $\mathrm{NOx}$}

The daytime increase in $\mathrm{O}_{3}$ concentration at the observational site is due to the active photochemistry of $\mathrm{O}_{3}$ precursors, Boundary Layer Height (BLH) variations, regional emissions, and changes in weather patterns. This type of $\mathrm{O}_{3}$ variation at urban and rural sites is attributed to the daytime in situ photochemical production from its precursor gases [70]. The diurnal variations of $\mathrm{O}_{3}$ and solar radiation is shown in Figure 2. From the figure, it is clear that the surface $\mathrm{O}_{3}$ concentrations gradually increasing after sunrise, attaining an extreme concentration during noontime and declining during night time. The enhancement in the $\mathrm{O}_{3}$ concentration relative to the increase in solar radiation indicates an active photochemical reaction in the presence of solar radiation. In our observation, it is found that the concentration of surface $\mathrm{O}_{3}$ reaches its peak value in the noon time, 30 min after the maximum intensity of solar radiation.

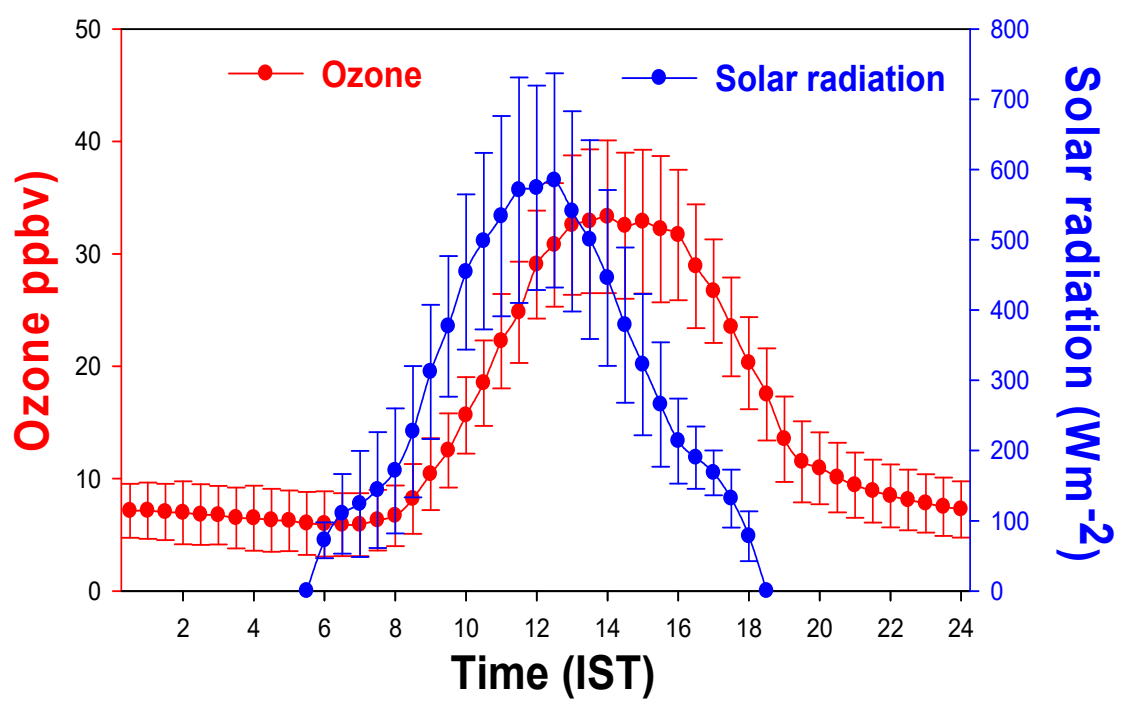

Figure 2. Diurnal variation of $\mathrm{O}_{3}$ and solar radiation.

The absolute water vapor content $\rho_{V}$ is evaluated from the measured values of relative humidity $(\mathrm{RH})$ and temperature $(\mathrm{T})$ using the empirical relation given by $[63,71]$.

$$
\begin{aligned}
& \rho_{\mathrm{S}}=\mathrm{A} \exp \left(18.9766-14.9595 \mathrm{~A}-2.4388 \mathrm{~A}^{2}\right) \\
& \rho_{V}=\rho_{\mathrm{S}}\left(\frac{\mathrm{RH}}{100}\right)\left[1-\left(\frac{\mathrm{RH}}{100}\right)\left(\frac{\rho_{\mathrm{S}} \mathrm{R}_{\mathrm{V}} \mathrm{T}}{\mathrm{P}}\right)\right]^{-1} \\
& \text { where } \mathrm{A}=\frac{\mathrm{T}_{0}}{\left(\mathrm{~T}_{0}+\mathrm{t}\right)}, \text { and } \mathrm{T}=\left(\mathrm{T}_{0}+\mathrm{t}\right)
\end{aligned}
$$


The average diurnal profile of $\mathrm{O}_{3}, \mathrm{NOx}$, and water vapor content over the study area is shown in Figure 3a. Generally, $\mathrm{NOx}\left(\mathrm{NO}+\mathrm{NO}_{2}\right)$ concentration was observed to be low during daytime and high during late night hours, and early in the morning hours. The main reason for the increase of NOx observed at night and early morning were due to the very low BLH and motor vehicular emissions [72,73].
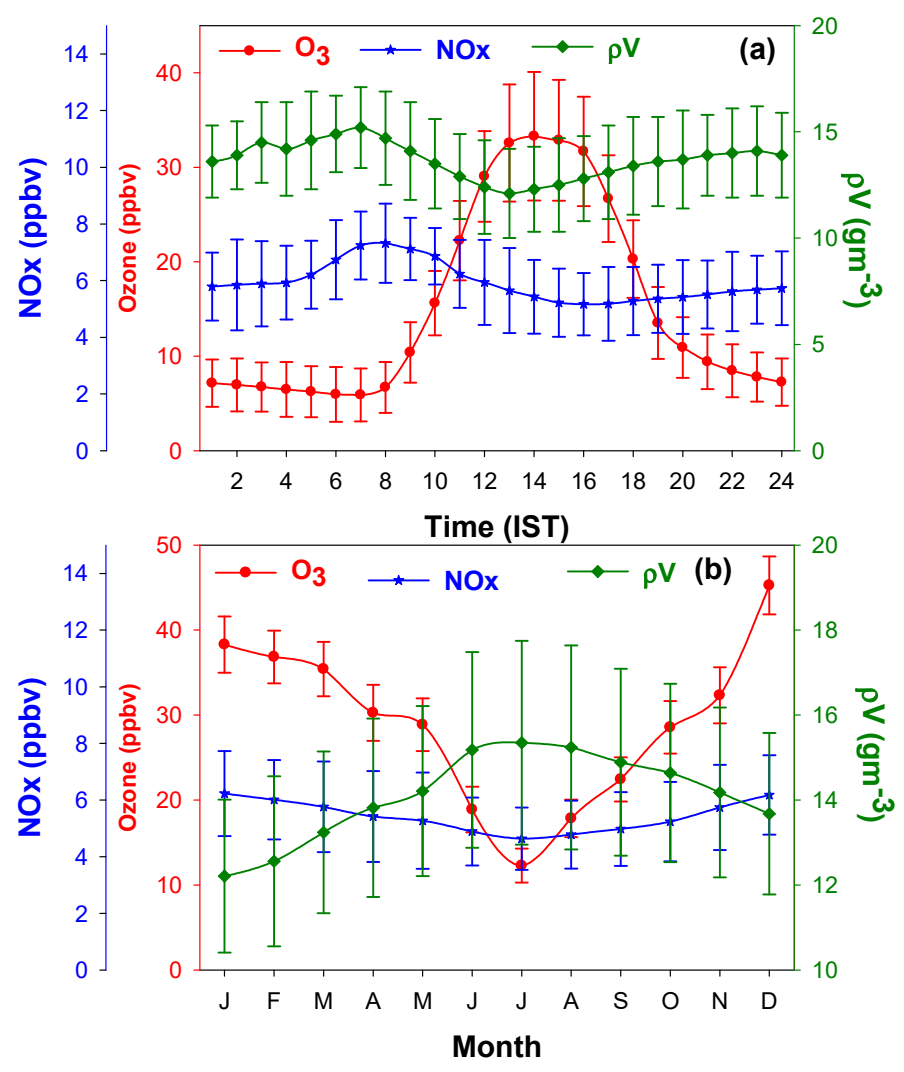

Figure 3. (a) Diurnal, (b) monthly variation of $\mathrm{O}_{3}$, $\mathrm{NOx}$, and water content for the period January 2013-December 2018.

In the presence of shallow BLH, the elevated levels of water vapor during monsoon and post-monsoon season acts as a detergent for the atmospheric chemistry [74-76]. The maximum $\left(15.2 \pm 1.9 \mathrm{gm}^{-3}\right)$ water vapor content is observed in the morning at 09:00, and the minimum $\left(12.1 \pm 2.1 \mathrm{gm}^{-3}\right)$ is observed in the noontime at 13:00. During evening hours, water vapor gradually increases until late at night due to the decline in temperature. From the figure, it is clear that water vapor and NOx have the same diurnal patterns, while surface $\mathrm{O}_{3}$ has just the opposite pattern. The monthly variation of surface $\mathrm{O}_{3}, \mathrm{NOx}$, and water content is shown in Figure 3b. The 24-h averaged monthly mean maximum $\left(15.35 \pm 2.3 \mathrm{gm}^{-3}\right)$ water vapor is observed in July due to monsoon and the minimum $\left(12.2 \pm 1.8 \mathrm{gm}^{-3}\right)$ is in January. Similarly, the daytime averaged monthly mean lowest $\mathrm{O}_{3}$ is observed in July and the maximum is in December. From the figure, it is clear that the increase in $\rho_{V}$ declines the $\mathrm{O}_{3}$ in this site.

The presence of water vapor in the atmosphere gives a radiative cooling and reduced photochemical process. Water vapor content in the form $\mathrm{HOx}\left(=\mathrm{OH}+\mathrm{HO}_{2}\right)$ radicals reacts with other chemical species in the atmosphere and can have a detrimental effect on $\mathrm{O}_{3}$ in the atmosphere [77-79].

\subsection{Impact of Meteorological Parameters on $\mathrm{O}_{3}$ and $\mathrm{NO}_{2}$}

Variations in meteorological parameters influence the efficiency of photochemical production and loss of surface $\mathrm{O}_{3}[38,80]$. Solar radiation and enhanced air temperatures play catalytic roles in chemical reactions, leading to surface $\mathrm{O}_{3}$ formation [81]. In our study, in situ $\mathrm{O}_{3}$ data shows that the $\mathrm{O}_{3}$ mixing 
ratio starts to increase after 9:00 IST and reaches a maximum value at about 13:30-14:30 IST and then decreases slowly. The concentrations reached its low value during the night hours. The photochemical production of surface $\mathrm{O}_{3}$ over a specific location is influenced by the concentration of its precursor gases. Consequently, the correlation among $\mathrm{O}_{3}, \mathrm{NO}_{2}$, and meteorological parameters was calculated for the daytime and is presented in Table 1.

Table 1. Correlation between $\mathrm{O}_{3}, \mathrm{NO}_{2}$, and weather parameters from January 2013 to December 2018 (correlation is significant at 0.01 level).

\begin{tabular}{ccccccc}
\hline Parameters & $\mathrm{O}_{3}$ & $\mathrm{NO}_{2}$ & Temperature & Solar Radiation & $\mathbf{R H}$ & Wind Velocity \\
\hline $\mathrm{O}_{3}$ & 1 & 0.68 & 0.89 & 0.74 & -0.82 & -0.76 \\
\hline $\mathrm{NO}_{2}$ & 0.68 & 1 & -0.62 & -0.48 & -0.44 & -0.38 \\
\hline Temperature & 0.89 & -0.62 & 1 & 0.64 & -0.48 & -0.42 \\
\hline Solar radiation & 0.74 & -0.48 & 0.64 & 1 & -0.54 & -0.38 \\
\hline Relative humidity & -0.82 & -0.44 & -0.48 & -0.54 & 1 & -0.36 \\
\hline Wind speed & -0.76 & -0.38 & -0.42 & -0.38 & -0.36 & 1 \\
\hline
\end{tabular}

It is evident that $\mathrm{O}_{3}$ variation is positively related to air temperature and is negatively related to RH. Statistical analysis of correlation coefficients showed that the most favorable parameters for the formation of $\mathrm{O}_{3}$ over the observational site are ambient air temperature, solar radiation, and the enhanced concentration of $\mathrm{NO}_{2}$.

\subsection{Impact of Air Temperature on $\mathrm{O}_{3}$ Production: A Neural Network Analysis}

The increase in atmospheric temperature has a significant impact on $\mathrm{O}_{3}$ production as it accelerates the chemical reactions in the atmosphere. Numerous studies have evaluated the temperature sensitivity of surface $\mathrm{O}_{3}$ production over different parts of the globe [33,82-91]. Solberg [48] reported a substantial increase in surface $\mathrm{O}_{3}$ with high temperatures during the observations of $\mathrm{O}_{3}$ and trace gases in the European Monitoring and Evaluation Programme (EMEP) network. Modeling studies by different groups $[83,84,90,92]$ found that high atmospheric temperatures increases the surface $\mathrm{O}_{3}$ concentration keeping constant VOCs and NOx concentrations. Pusede [86], found that in a polluted environment with rich NOx concentrations, $\mathrm{O}_{3}$ and atmospheric temperature show a positive relationship and the temperature accelerates the $\mathrm{O}_{3}$ productions. As a consequence of global warming, this positive $\mathrm{O}_{3}$-temperature relationship causes a significant decrease in the quality of the air without anthropogenic emissions in industrial areas and is referred to as a climate penalty [93].

In the FFNN, the input parameters given were five-minute interval surface meteorological and observed trace gases data obtained from the ground-based measurements. We do not have the facility to carry out the measurement of other trace species; hence, their values were set to represent a typical rural environment. One-quarter (25\%) of the total available datasets in the winter and summer months were selected for model analysis. The environmental parameters used for artificial neural network simulations are given in Table 2.

To detect the effect of atmospheric temperature on the production of surface $\mathrm{O}_{3}$, the air temperature was gradually raised from 16 to $44^{\circ} \mathrm{C}$, keeping the values of solar radiation and relative humidity at $850 \mathrm{Wm}^{-2}$ and $60 \%$ respectively and other input parameters at the respective average values. These values were selected to represent a distinctive level of meteorological parameters during the days of winter months, which represent a higher concentration of $\mathrm{O}_{3}$ in the atmosphere of Kannur. Similarly, in order to detect the effect of solar radiation on the production of surface $\mathrm{O}_{3}$, the intensity of solar radiation was varied from 0 to $900 \mathrm{Wm}^{-2}$, keeping all other parameters constant at their average value. A similar method was adopted for determining the effect of $\mathrm{RH}$ on surface $\mathrm{O}_{3}$. Figure 4 shows how the changes in $\mathrm{O}_{3}$ depend on the variation of temperature, solar radiation, and $\mathrm{RH}$ when the other parameters are fixed. From the figure, it is clear that the increase in atmospheric temperature and solar 
radiation enhances the concentration of surface $\mathrm{O}_{3}$. However, the values of temperature and solar radiation lines spread out at a high concentration of $\mathrm{O}_{3}$, which in turn makes solar radiation levels more nonlinear. Therefore, even if the intensity of solar radiation is increased again, the concentration of $\mathrm{O}_{3}$ cannot be increased. Thus, it must be inferred that beyond a threshold of solar radiation, the photolysis of $\mathrm{NO}_{2}$ may not be the limiting factor for in situ surface $\mathrm{O}_{3}$ creation for a particular environment. This revealed that strong solar radiation and a high atmospheric temperature are the most imperative factors controlling the enhanced photochemical $\mathrm{O}_{3}$ formation over Kannur.

Table 2. Input parameters used for artificial neural network analysis.

\begin{tabular}{cccc}
\hline Parameters & Minimum & Maximum & Average \\
\hline Ozone $(\mathrm{ppbv})$ & 10 & 50 & 30 \\
\hline Total ozone column $(\mathrm{DU})$ & 200 & 280 & 240 \\
\hline $\mathrm{NO}(\mathrm{ppbv})$ & 0.5 & 3 & 2 \\
\hline $\mathrm{NO}_{2}(\mathrm{ppbv})$ & 0.5 & 5 & 3 \\
\hline Surface air temperature $\left({ }^{\circ} \mathrm{C}\right)$ & 16 & 44 & 25 \\
\hline Relative humidity $(\%)$ & 40 & 90 & 65 \\
\hline Solar radiation $\left(\mathrm{Wm}^{-2}\right)$ & 0 & 900 & 400 \\
\hline Wind speed $\left(\mathrm{ms}^{-1}\right)$ & 0 & 10 & 2 \\
\hline
\end{tabular}

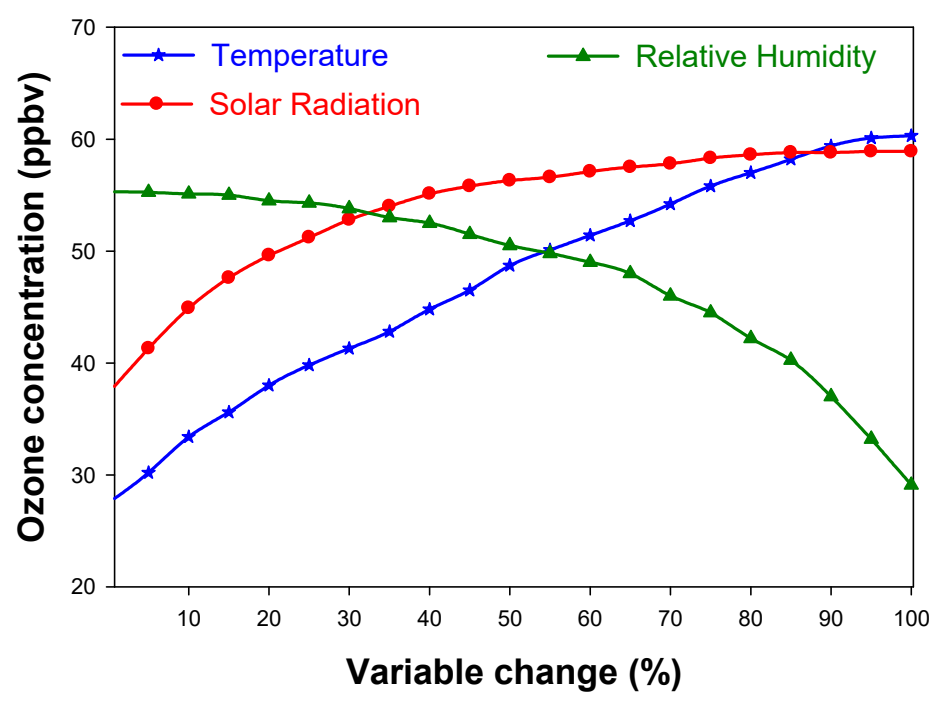

Figure 4. Neural network output for $\mathrm{O}_{3}$ concentration with respect to the variation of temperature, solar radiation, and relative humidity.

Correlations between the observed temperature with the observed and ANN modeled ozone, observed solar radiation with observed and ANN modeled ozone, and observed relative humidity with observed and ANN modeled ozone has been made and are shown in Figure 5. It is found that the observed and model outputs of the ozone are statistically significant with the meteorological parameters. Statistical analysis (Pearson's test) is performed, and the correlation coefficient is found to be significant at the $95 \%$ confidence level. The correlation coefficients obtained for the observed temperature, solar radiation, and relative humidity with the observed ozone are $0.92,0.90$, and 0.86 , and for the modeled ozone, they are $0.94,0.91$, and 0.89 , respectively. 

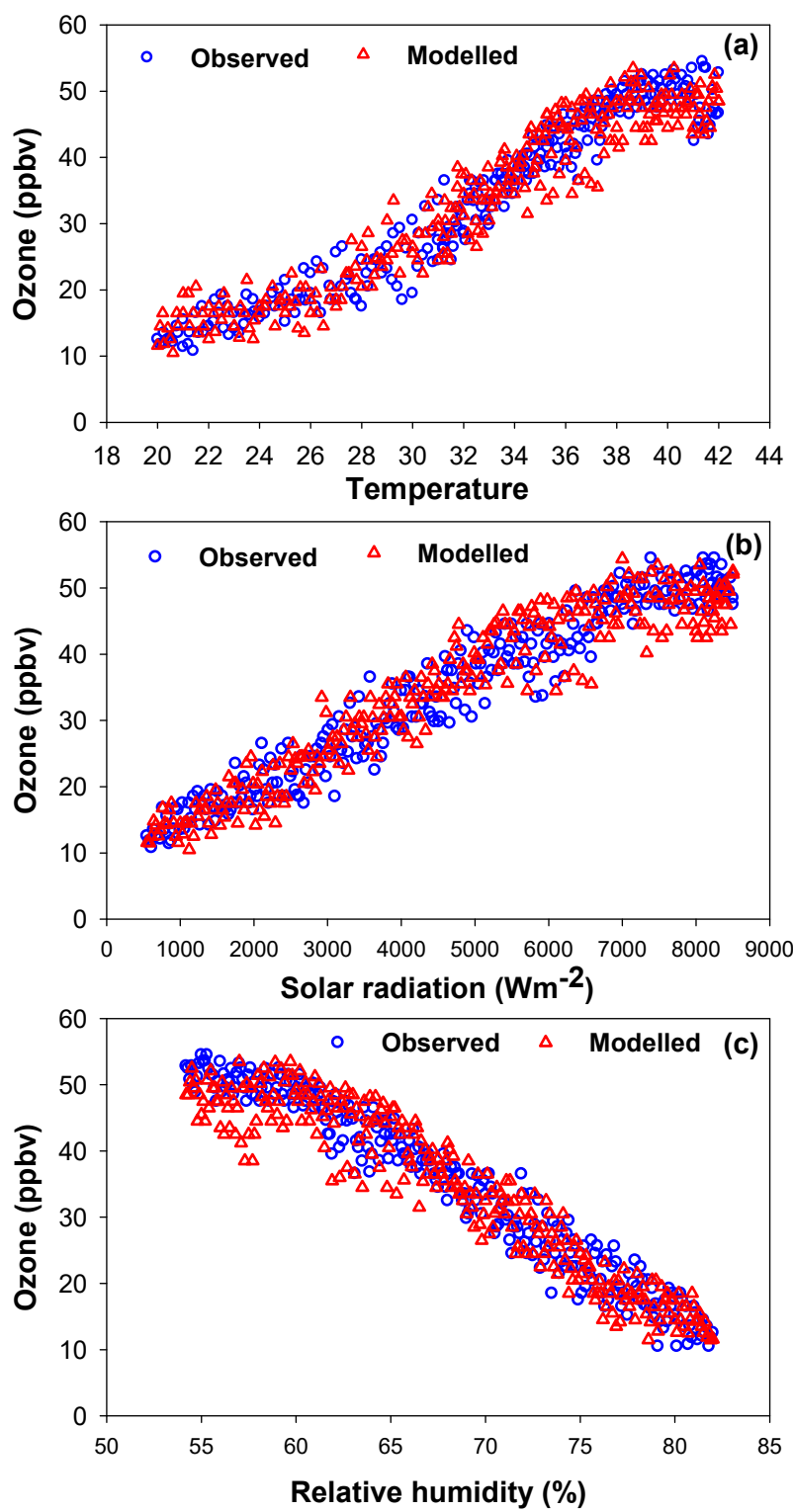

Figure 5. Scatter plot showing the correlations among (a) observed temperature, (b) solar radiation, and (c) relative humidity with observed and modelled ozone.

Figure 6 shows the relationship between the observed daytime maximum $\mathrm{O}_{3}$ concentrations and the corresponding model predicted $\mathrm{O}_{3}$ concentrations. The lower observed concentrations yielded lower simulated results and higher simulated concentrations at observed higher values. The model-simulated output $\mathrm{O}_{3}$ concentrations with the observed concentration shows a positive linear correlation with the correlation coefficient $(\mathrm{r}=0.89)$. It can be observed that given the values of other available parameters, the accuracy of the modeled output can be greatly improved. Since $\mathrm{O}_{3}$ formation is a nonlinear process involving complex reactions, it is clear that the use of an ANN model offers greater consistency and a high degree of accuracy on $\mathrm{O}_{3}$ modeling using different forecasters.

Figure 7a indicates the assessment of the annual average $24 \mathrm{~h}$ variations of $\mathrm{O}_{3}$ observed from January-December 2013 and from January-December 2018. The average diurnal variation of $\mathrm{O}_{3}$ on a yearly basis is computed for every hour from January to December. The average diurnal variation of $\mathrm{O}_{3}$ in 2013 shows the extreme mixing ratio $(31.97 \pm 8.52) \mathrm{ppbv}$ at 15:00, and in 2018, it shows a maximum (35.47 \pm 10.5$)$ ppbv at 15:00. We also observed an increasing trend of $\mathrm{O}_{3}$ during noontime in 2018 as compared to 2013, and the increase is $10.94 \%$. The corresponding minimum of $\mathrm{O}_{3}$ mixing 
ratio $(6.22 \pm 0.84)$ and $(7.46 \pm 0.9 .7)$ ppbv was observed at 07:00 in the morning of respective years. The favorable meteorological conditions for the formation of $\mathrm{O}_{3}$ are intense solar radiation, low wind speed, shallow boundary layer height, and a high surface air temperature. The mean air temperature at any location depends on various factors, among which latitude, altitude, proximity to the sea, temperature of the sea, and exposure are the major ones [94].

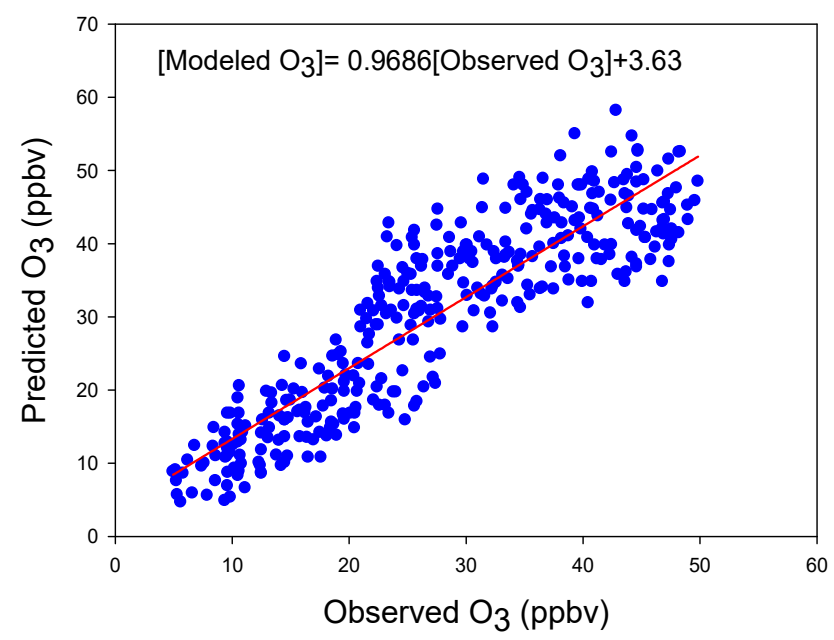

Figure 6. Correlation between predicted daytime $\mathrm{O}_{3}$ concentration using neural model and observed daytime maximum $\mathrm{O}_{3}$ concentration.
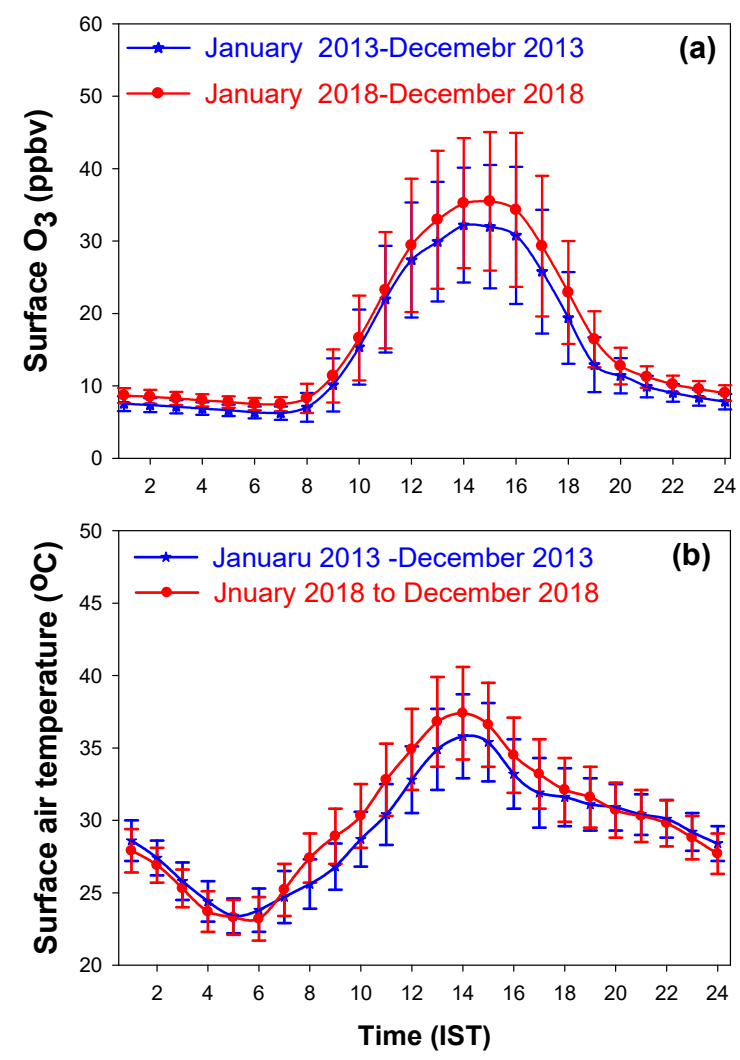

Figure 7. Annual mean 24-h variations of (a) $\mathrm{O}_{3}$ and (b) surface air temperature for the years 2013 and 2018.

Figure $7 \mathrm{~b}$ shows the comparison of annual average diurnal variations of surface air temperature recorded from January to December 2013 and from January to December 2018. During 2013, 
the maximum $(35.8 \pm 2.9)$ daytime temperature was recorded at $14: 00$, and in 2018 , the maximum $(37.4 \pm 3.2)$ temperature was recorded at 14:00. The daytime temperature was found to be increased from $35.8 \pm 2.9^{\circ} \mathrm{C}$ to $37.4 \pm 3.2{ }^{\circ} \mathrm{C}$ (from 2013 to 2018 ), and this temperature increase $(4.46 \%$ ) was accompanied by the increase in the surface $\mathrm{O}_{3}$ concentration from $31.97 \pm 8.52$ to $35.47 \pm 10.5 \mathrm{ppbv}$. Thus, the enhancement in $\mathrm{O}_{3}(10.94 \%)$ is well-matched with an enhancement in surface air temperature $(4.46 \%)$. The apparent effect of $\mathrm{O}_{3}$ on atmospheric temperature was also evident in the intermediate years. Thus, a fairly small variation in temperature can significantly enhance ozone production. Surface $\mathrm{O}_{3}$ concentration reaches its peak value when the air temperature is a maximum, which indicates that $\mathrm{O}_{3}$ concentrations are directly related to temperature. The atmospheric air temperature changes with seasons of the year and time of the day. Over all the days, it was observed that the maximum temperature was reached at 14:00 IST. This indicates that the air temperature is significantly influencing the production of $\mathrm{O}_{3}$, and photochemistry is the dominant mechanism controlling the concentration level of $\mathrm{O}_{3}$ at Kannur.

\subsection{Long-Term Observed Variations of $\mathrm{O}_{3}, \mathrm{NO}$, and $\mathrm{NO}_{2}$}

The following Table 3 is a description of the hourly average concentration of trace gas along a day, averaged over the period 2013-2018. Depending on the amount of sunlight, the ground level $\mathrm{O}_{3}$ increases whereas the concentrations of NOx reduced. $\mathrm{O}_{3}$ levels can be seen enhancing in the early morning hours of the year except for the rainy days of the monsoon months. Usually, $\mathrm{O}_{3}$ levels are recorded high in the late afternoon. The chemical reaction with NO is the main reason for the decrease in $\mathrm{O}_{3}$ observed at night. From our ground-based observations, it is found that the maximum number of ozone concentrations were observed in the range of 5-10 ppbv, mainly belonging to the night hours. The second-largest distribution of ozone concentration was observed between 10 and 20 ppbv. A substantial upsurge was noticed between 25 and 40 ppbv and 40-60 ppbv due to the enhanced $\mathrm{O}_{3}$ mixing ratio during daytime in clear sky days. Thus, it is revealed that $65 \%$ of the total $\mathrm{O}_{3}$ concentration lies between 5 and 20 ppbv and 30\% lies between 20 and 45 ppbv, whereas merely 5\% fluctuates from 46 to 60 ppbv.

Table 3. The average hourly $\mathrm{O}_{3}, \mathrm{NO}$, and $\mathrm{NO}_{2}$ at Kannur.

\begin{tabular}{cccc}
\hline Time & $\mathrm{O}_{3}(\mathbf{p p b v})$ & $\mathrm{NO}(\mathbf{p p b v})$ & $\mathrm{NO}_{2}(\mathrm{ppbv})$ \\
\hline 1 & $5.79 \pm 1.05$ & $1.67 \pm 0.22$ & $1.89 \pm 0.28$ \\
\hline 2 & $5.66 \pm 0.90$ & $1.65 \pm 0.30$ & $1.91 \pm 0.36$ \\
\hline 3 & $5.49 \pm 0.88$ & $1.64 \pm 0.35$ & $1.90 \pm 0.42$ \\
\hline 4 & $5.29 \pm 0.88$ & $1.65 \pm 0.37$ & $1.90 \pm 0.44$ \\
\hline 5 & $5.06 \pm 0.82$ & $1.61 \pm 0.41$ & $1.90 \pm 0.47$ \\
\hline 6 & $4.77 \pm 0.90$ & $1.56 \pm 0.38$ & $1.88 \pm 0.48$ \\
\hline 7 & $4.57 \pm 0.80$ & $1.56 \pm 0.32$ & $1.93 \pm 0.50$ \\
\hline 8 & $5.50 \pm 1.63$ & $1.67 \pm 0.38$ & $2.06 \pm 0.50$ \\
\hline 9 & $8.76 \pm 3.15$ & $1.81 \pm 0.42$ & $2.22 \pm 0.46$ \\
\hline 10 & $13.99 \pm 5.74$ & $1.85 \pm 0.50$ & $2.22 \pm 0.39$ \\
\hline 11 & $20.33 \pm 8.74$ & $1.71 \pm 0.51$ & $1.99 \pm 0.42$ \\
\hline 12 & $26.06 \pm 10.43$ & $1.55 \pm 0.48$ & $1.75 \pm 0.43$ \\
\hline 13 & $30.04 \pm 10.72$ & $1.36 \pm 0.41$ & $1.53 \pm 0.39$ \\
\hline 14 & $31.42 \pm 10.48$ & $1.13 \pm 0.25$ & $1.35 \pm 0.39$ \\
\hline 15 & $32.29 \pm 11.09$ & $1.05 \pm 0.23$ & $1.25 \pm 0.43$ \\
\hline
\end{tabular}


Table 3. Cont.

\begin{tabular}{cccc}
\hline Time & $\mathbf{O}_{3}(\mathbf{p p b v})$ & $\mathbf{N O}(\mathbf{p p b v})$ & $\mathbf{N O}_{2}(\mathbf{p p b v})$ \\
\hline 16 & $30.51 \pm 11.80$ & $1.04 \pm 0.22$ & $1.21 \pm 0.44$ \\
\hline 17 & $25.63 \pm 11.11$ & $1.12 \pm 0.25$ & $1.24 \pm 0.40$ \\
\hline 18 & $19.23 \pm 7.55$ & $1.24 \pm 0.30$ & $1.3 \pm 0.34$ \\
\hline 19 & $12.79 \pm 3.88$ & $1.35 \pm 0.31$ & $1.44 \pm 0.28$ \\
\hline 20 & $9.95 \pm 2.35$ & $1.46 \pm 0.30$ & $1.57 \pm 0.27$ \\
\hline 21 & $8.45 \pm 1.36$ & $1.55 \pm 0.31$ & $1.66 \pm 0.28$ \\
\hline 22 & $7.50 \pm 1.07$ & $1.64 \pm 0.33$ & $1.76 \pm 0.30$ \\
\hline 23 & $6.83 \pm 1.04$ & $1.75 \pm 0.33$ & $1.89 \pm 0.30$ \\
\hline 24 & $6.30 \pm 1.10$ & $1.84 \pm 0.34$ & $2.17 \pm 0.29$ \\
\hline
\end{tabular}

Statistical analysis of the concentration of observed trace gases $\left(\mathrm{O}_{3}, \mathrm{NO}, \mathrm{NO}_{2}, \mathrm{NOx}\right)$ is listed in Table 4. During January-December 2013, the average concentrations of $\mathrm{O}_{3}$ was $31.97 \pm 8.52 \mathrm{ppbv}$ and $\mathrm{NO}, \mathrm{NO}_{2}$, and NOx were $2.19 \pm 0.45,2.32 \pm 0.65$, and $4.51 \pm 0.78 \mathrm{ppbv}$, respectively. Similarly, during January-December 2018, the average concentrations of $\mathrm{O}_{3}$ was $35.47 \pm 10.5 \mathrm{ppbv}$ and for $\mathrm{NO}, \mathrm{NO}_{2}$, and NOx they were $2.46 \pm 0.92,2.68 \pm 1.07$, and $5.14 \pm 1.08 \mathrm{ppbv}$ respectively. The annual average $\mathrm{O}_{3}$ concentration changes from $31.97 \pm 8.52$ to $35.47 \pm 10.5 \mathrm{ppbv}$ and NOx varied from $4.51 \pm 0.78$ to $5.14 \pm 1.08$ during 2013 to 2018 . This variation showing an increasing trend of $\mathrm{O}_{3}(10.94 \%)$ and $\mathrm{NOx}$ $(13.96 \%)$ over the observational site during the period 2013 to 2018.

Table 4. Statistical analysis of the observed trace gases during 2013-2018 at Kannur.

\begin{tabular}{|c|c|c|c|c|c|}
\hline \multirow{2}{*}{ Duration } & \multirow{2}{*}{ Statistics } & \multicolumn{4}{|c|}{ Gases } \\
\hline & & $\mathrm{O}_{3}$ & NO & $\mathrm{NO}_{2}$ & NOx \\
\hline \multirow{5}{*}{$\begin{array}{l}1 \text { January 2013- } \\
31 \text { December } 2013\end{array}$} & Average & 31.97 & 2.19 & 2.32 & 4.51 \\
\hline & Standard deviation & 8.52 & 0.45 & 0.65 & 0.78 \\
\hline & Daytime maximum & 50.2 & 2.68 & 2.78 & 5.21 \\
\hline & Daytime minimum & 11.6 & 0.98 & 0.85 & 2.22 \\
\hline & Number of data & 37,440 & 37,120 & 37,120 & 37,120 \\
\hline \multirow{5}{*}{$\begin{array}{l}1 \text { January 2014- } \\
31 \text { December } 2014\end{array}$} & Average & 32.2 & 2.32 & 2.45 & 4.77 \\
\hline & Standard deviation & 9.6 & 0.65 & 0.74 & 0.89 \\
\hline & Daytime maximum & 52.2 & 2.75 & 2.88 & 5.32 \\
\hline & Daytime minimum & 10.8 & 1.02 & 1.12 & 2.32 \\
\hline & Number of data & 38,160 & 38,120 & 38,120 & 38,120 \\
\hline \multirow{5}{*}{$\begin{array}{l}1 \text { January 2015- } \\
31 \text { December } 2015\end{array}$} & Average & 33.75 & 2.27 & 2.48 & 4.75 \\
\hline & Standard deviation & 10.6 & 0.69 & 0.78 & 0.88 \\
\hline & Daytime maximum & 53.55 & 2.82 & 2.78 & 5.46 \\
\hline & Daytime minimum & 12.2 & 1.12 & 1.08 & 2.38 \\
\hline & Number of data & 38,880 & 36,520 & 36,520 & 36,520 \\
\hline
\end{tabular}


Table 4. Cont.

\begin{tabular}{|c|c|c|c|c|c|}
\hline \multirow{2}{*}{ Duration } & \multirow{2}{*}{ Statistics } & \multicolumn{4}{|c|}{ Gases } \\
\hline & & $\mathrm{O}_{3}$ & NO & $\mathrm{NO}_{2}$ & NOx \\
\hline \multirow{5}{*}{$\begin{array}{l}1 \text { January 2016- } \\
31 \text { December } 2016\end{array}$} & Average & 34.88 & 2.35 & 2.52 & 4.87 \\
\hline & Standard deviation & 11.1 & 0.72 & 0.88 & 0.94 \\
\hline & Daytime maximum & 56.12 & 2.88 & 2.98 & 5.48 \\
\hline & Daytime minimum & 12.4 & 1.08 & 1.12 & 2.42 \\
\hline & Number of data & 41,760 & 38,450 & 38,450 & 38,450 \\
\hline \multirow{5}{*}{$\begin{array}{l}1 \text { January 2017- } \\
31 \text { December } 2017\end{array}$} & Average & 35.12 & 2.41 & 2.54 & 4.95 \\
\hline & Standard deviation & 12.2 & 0.88 & 0.98 & 0.98 \\
\hline & Daytime maximum & 57.6 & 2.86 & 2.89 & 5.59 \\
\hline & Daytime minimum & 12.02 & 1.21 & 1.18 & 2.46 \\
\hline & Number of data & 40,880 & 40,660 & 40,660 & 40,660 \\
\hline \multirow{5}{*}{$\begin{array}{l}1 \text { January 2018- } \\
31 \text { December } 2018\end{array}$} & Average & 35.47 & 2.46 & 2.68 & 5.14 \\
\hline & Standard deviation & 10.5 & 0.92 & 1.07 & 1.08 \\
\hline & Daytime maximum & 58.5 & 2.92 & 2.96 & 5.72 \\
\hline & Daytime minimum & 12.29 & 1.24 & 1.22 & 2.41 \\
\hline & Number of data & 41,320 & 40,240 & 40,240 & 40,240 \\
\hline
\end{tabular}

These apparent variations are caused by the changes in atmospheric boundary layer above the Earth's surface in the presence of sunlight, chemical reactions of trace gases, and changes in the regional climate. In addition to observational studies, recent model simulations $[95,96]$ revealed the substantial increase of surface $\mathrm{O}_{3}$ concentrations over the East and South Asian regions. Future trends in troposphere $\mathrm{O}_{3}$ are considered with greater attention in modeling studies.

\subsection{NCAR-MM Model Simulation}

The NCAR Master Mechanism is a chemical box model developed at National Centre for Atmospheric Research, Boulder, CO, USA, which was used to simulate the diurnal variation of $\mathrm{O}_{3}$, primed with ground-based observations. This model computes the time-dependent chemical evolution of an air parcel, taking into account the detailed gas phase chemistry, which consists of 5000 reactions among the 2000 species. The model was initiated with 12 trace species $\left(\mathrm{O}_{3}, \mathrm{H}_{2} \mathrm{O}, \mathrm{CO}, \mathrm{CH}_{4}, \mathrm{NO}, \mathrm{NO}_{2}\right.$, $\mathrm{OH}, \mathrm{HO}_{2}, \mathrm{CH}_{2} \mathrm{O}, \mathrm{C}_{3} \mathrm{H}_{6}$, isoprene, and i-butane), while $\mathrm{N}_{2}, \mathrm{O}_{2}$, and photon energy are hard-wired in the model. Based on these species, 1031 reactions are used in the simulation. This model has been used to understand the diurnal variation of surface $\mathrm{O}_{3}$ for different seasons with the observed diurnal patterns. Many groups $[61-64,97,98]$ used the NCAR-MMP model to realize the photochemistry of trace gas in the lower atmosphere over different regions around the globe, and they found that the simulated results are consistent with the observations. The details of the NCAR-MMP model are described by Aumont [99] and Madronich [100]. The initial and background (B.G) values of trace gases and environmental parameters used for box model simulation for different seasons are shown in Table 5. We do not have the facilities for the measurement of $\mathrm{CH}_{2} \mathrm{O}, \mathrm{C}_{2} \mathrm{H}_{6}$, and isoprene and other trace species at the observational site; thus, the data of a typical rural environment available from the other locations were given to the modeling. 
Table 5. Initial and background (BG) values of trace gases and environmental parameters set for model simulation for different seasons.

\begin{tabular}{|c|c|c|c|c|c|c|c|c|c|c|}
\hline \multirow{3}{*}{ Parameters } & \multicolumn{10}{|c|}{ Season } \\
\hline & \multicolumn{2}{|c|}{ Winter } & \multicolumn{2}{|c|}{ Summer } & \multicolumn{2}{|c|}{ Monsoon } & \multicolumn{2}{|c|}{ Post Monsoon } & \multicolumn{2}{|c|}{ Annual } \\
\hline & Initial & B.G & Initial & B.G & Initial & B.G & Initial & B.G & Initial & B.G \\
\hline $\mathrm{O}_{3}(\mathrm{ppbv})$ & 36 & 32 & 30 & 38 & 14 & 28 & 22 & 34 & 25.5 & 33 \\
\hline $\mathrm{CO}$ (ppbv) & 320 & 325 & 280 & 120 & 220 & 300 & 260 & 220 & 270 & 241 \\
\hline $\mathrm{CH}_{4}(\mathrm{ppbv})$ & 3200 & 1800 & 2250 & 1700 & 1800 & 1600 & 2100 & 1650 & 2330 & 1687.5 \\
\hline $\mathrm{CH}_{2} \mathrm{O}$ (ppbv) & 0.4 & 0.5 & 0.5 & 0.49 & 0.6 & 0.48 & 0.7 & 0.45 & 0.55 & 0.48 \\
\hline $\mathrm{C}_{2} \mathrm{H}_{6}$ (ppbv) & 0.96 & 1.1 & 1 & 0.9 & 0.8 & 0.95 & 0.9 & 1.05 & 0.92 & 1.01 \\
\hline Isoprene (ppbv) & 1 & 1.1 & 0.8 & 1.2 & 0.86 & 1 & 0.92 & 1.05 & 0.89 & 1.08 \\
\hline Temperature (K) & \multicolumn{2}{|c|}{298} & \multicolumn{2}{|c|}{308} & \multicolumn{2}{|c|}{300} & \multicolumn{2}{|c|}{304} & \multicolumn{2}{|c|}{302} \\
\hline $\mathrm{RH}(\%)$ & \multicolumn{2}{|c|}{72} & \multicolumn{2}{|c|}{66} & \multicolumn{2}{|c|}{80} & \multicolumn{2}{|c|}{74} & \multicolumn{2}{|c|}{73} \\
\hline $\mathrm{O}_{3}$ column $(\mathrm{DU})$ & \multicolumn{2}{|c|}{340} & \multicolumn{2}{|c|}{360} & \multicolumn{2}{|c|}{260} & \multicolumn{2}{|c|}{280} & \multicolumn{2}{|c|}{310} \\
\hline $\mathrm{AOD}$ at $550 \mathrm{~nm}$ & \multicolumn{2}{|c|}{0.58} & \multicolumn{2}{|c|}{0.52} & \multicolumn{2}{|c|}{0.30} & \multicolumn{2}{|c|}{0.42} & \multicolumn{2}{|c|}{0.45} \\
\hline $\begin{array}{c}\text { Aerosol single } \\
\text { scattering albedo }\end{array}$ & \multicolumn{2}{|c|}{0.66} & \multicolumn{2}{|c|}{0.72} & \multicolumn{2}{|c|}{0.58} & \multicolumn{2}{|c|}{0.62} & \multicolumn{2}{|c|}{0.65} \\
\hline $\begin{array}{c}\text { Aerosol Angstrom } \\
\text { coefficient }\end{array}$ & \multicolumn{2}{|c|}{0.98} & \multicolumn{2}{|c|}{0.88} & \multicolumn{2}{|c|}{0.60} & \multicolumn{2}{|c|}{0.72} & & 80 \\
\hline
\end{tabular}

The model-simulated variation of $\mathrm{O}_{3}$ along with the observed diurnal variation for winter and summer seasons (averaged over the period 2013-2018) are shown in Figure 8a,b. In the winter season, the north easterly winds are quite predominant, which brings more pollution to this site, experiencing less humidity. The existence of a shallow boundary layer in winter may apparently increase the ozone concentration. This environment is more influenced by the land mass during winter, which elevates the ozone mixing at this site. In the monsoon season due to low temperature, solar radiation, and high humidity, $\mathrm{O}_{3}$ production is minimum. The seasonal mean values of $\mathrm{O}_{3}$ for the study period showed the daytime maximum in winter followed by summer and a minimum during the monsoon season. The clear sky days in the winter season significantly contribute an active photochemistry in the presence of a shallow boundary layer. From these figures, it is clear that the box model-simulated $\mathrm{O}_{3}$ variation is in tune with the diurnal profile of $\mathrm{O}_{3}$. Likewise, regarding the observed variations, the modeled $\mathrm{O}_{3}$ also starts increasing after the sunrise, attains its maximum at noontime, and gradually decreases over the evening hours. Figure $8 c, d$ show the scatter plot of observed and modeled $\mathrm{O}_{3}$ in the winter and summer seasons respectively for their correlation. The correlation between the modeled and the measured $\mathrm{O}_{3}$ is well-matched for winter $(r=0.97)$ and summer $(r=0.91)$ seasons. 

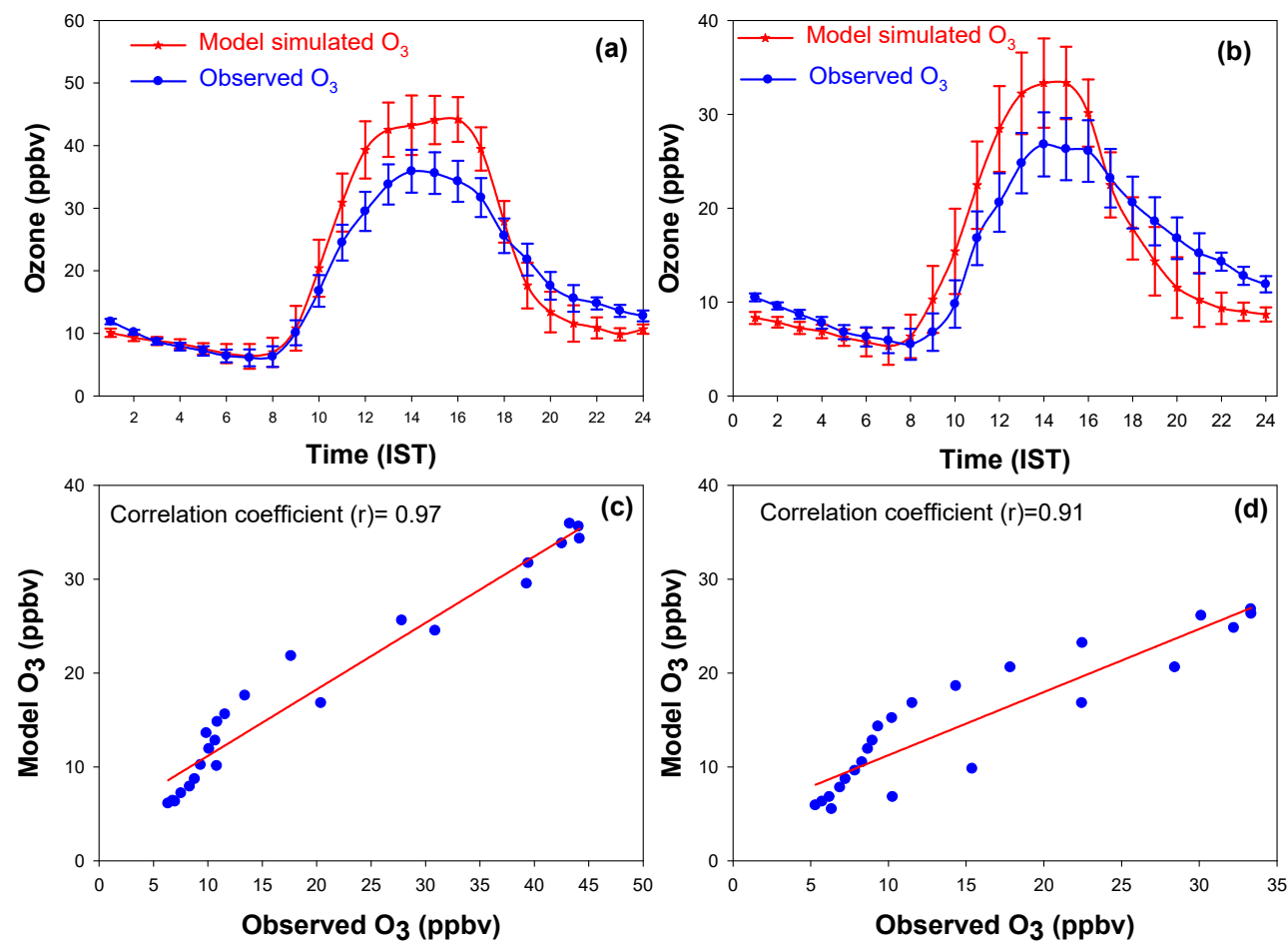

Figure 8. Diurnal variation of measured (averaged over the period 2013-2018) and modeled $\mathrm{O}_{3}$ for (a) winter, (b) summer, (c) scatter plot showing the correlation between model $\mathrm{O}_{3}$ and measured $\mathrm{O}_{3}$ for winter, (d) summer.

The model-simulated variation of $\mathrm{O}_{3}$ along with the observed diurnal variation for the monsoon and post-monsoon seasons (averaged over the period 2013-2018) are shown in Figure 9a,b, respectively. It is clear from these figures that the box model-simulated $\mathrm{O}_{3}$ variation is well-matched with the diurnal profile of $\mathrm{O}_{3}$ for both the seasons. Figure $9 \mathrm{c}, \mathrm{d}$ shows the scatter plot of observed and modeled $\mathrm{O}_{3}$ for the winter and summer seasons, respectively. The linear correlation coefficient between the model simulation and the observed $\mathrm{O}_{3}$ is well-matched $(\mathrm{r}=0.90)$ for the monsoon and $(\mathrm{r}=0.88)$ post-monsoon seasons.

The annual average diurnal variation of $\mathrm{O}_{3}$ and its model-simulated variation is shown in Figure 10a. The model-simulated $\mathrm{O}_{3}$ variation is well-matched with the diurnal profile of observed $\mathrm{O}_{3}$. The correlation coefficient existing between the modeled simulation and the observed profile is $r=0.82$, and it is shown in the Figure 10b. The results from the model simulation confirm that winter has a maximum concentration followed by summer and the post monsoon; and there is less concentration in the monsoon season. The model result shows that the $\mathrm{O}_{3}$ produced and decayed in the atmosphere of Kannur is mainly due to the photochemical reactions involving precursors. It can be seen that the increase in surface air temperature, solar radiation, and the variations in BLH also significantly affect the $\mathrm{O}_{3}$ levels during the daytime. In the model simulation, we were not able to include the transport of ozone and its precursors. Thus, the model output gives the production of ozone and its destruction employing chemical reactions only. Possibly, the observed and modeled shift may be due to the transport effect or the influence of other parameters that are currently not observed over the location. 

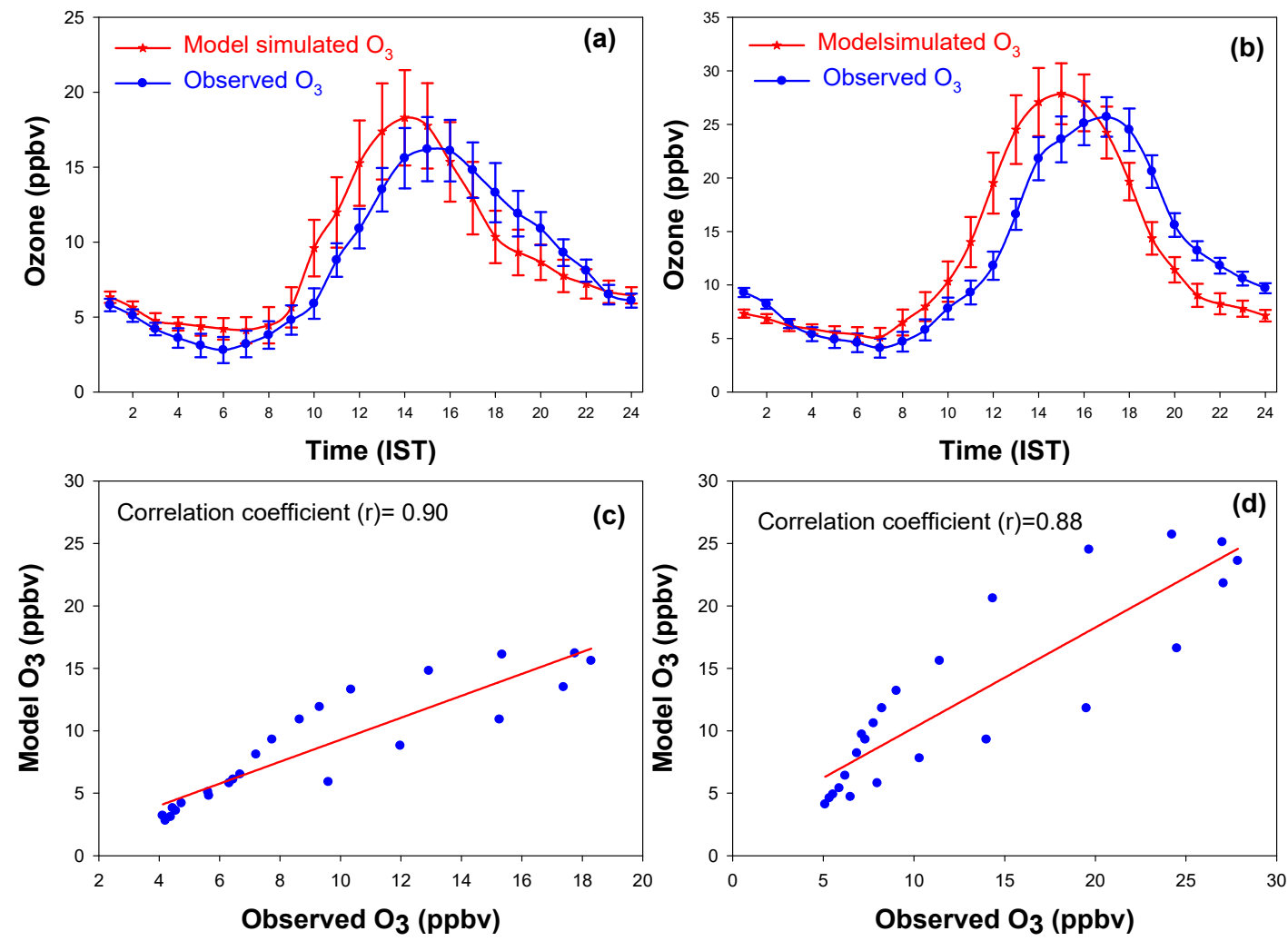

Figure 9. Diurnal variation of measured (averaged over the period 2013-2018) and modeled $\mathrm{O}_{3}$ for (a) monsoon, (b) post monsoon, and (c) scatter plot showing the correlation between model $\mathrm{O}_{3}$ and measured $\mathrm{O}_{3}$ for monsoon, (d) post monsoon.
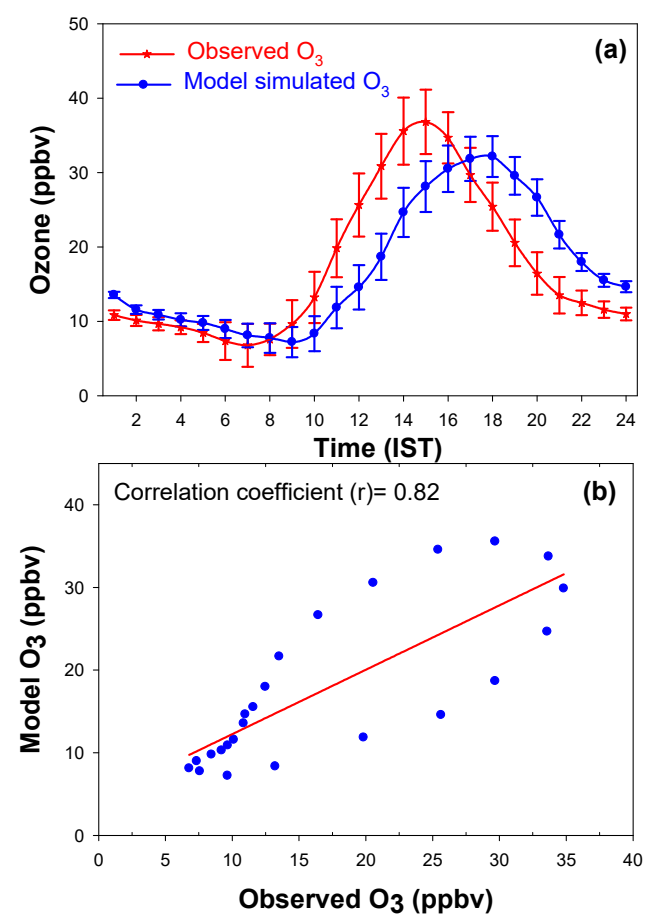

Figure 10. Yearly average (over the period 2013-2018) (a) diurnal profile of measured and modeled $\mathrm{O}_{3}$, (b) correlation between modeled $\mathrm{O}_{3}$ and measured $\mathrm{O}_{3}$. 


\subsection{Comparison of $\mathrm{O}_{3}$ with Other Observational Sites}

Continuous observations and studies of surface $\mathrm{O}_{3}$ in India began about 30 years ago and are currently underway in more than 20 various locations [14,24,60,62,76,101-118]. The diurnal and seasonal variation of surface $\mathrm{O}_{3}$ over Kannur shows a classic profile of a rural area, which is strongly prejudiced by seasonal changes, similar to other places in India. For a comparison, Table 6 represents the observed higher and lower surface $\mathrm{O}_{3}$ during the daytime at Kannur and other locations in India. The important thing to understand from this table is that in the southwestern parts of India, the highest concentration of $\mathrm{O}_{3}$ are observed in the winter and summer seasons. The enhanced $\mathrm{O}_{3}$ concentrations during the winter seasons are mainly due to th higher local emissions of precursor gases, long-range transport of continental pollutants, and the presence of a shallower boundary layer height. Due to a reduced photochemical process, all the observational sites show a very low concentration of $\mathrm{O}_{3}$ in the monsoon season. Strong convective activities, intense rainfall, and the flow of marine air are the major causes of reduced photochemical activities in monsoon. The monthly average daytime $\mathrm{O}_{3}$ concentration observed at Kannur is lower than the $\mathrm{O}_{3}$ concentration observed at Bhubaneswar, Mohal Kullu, Ootty, Pantnagar, Dayalbag and Nainital, Jodhpur, NCR Delhi, Udaipur, and Trivandrum. Kannur shows a wintertime maximum $\mathrm{O}_{3}$ similar to that observed at Trivandrum, Delhi, Port Blair, and Ootty. At the other observational sites, such as Agra, Kanpur, Anantapur, and Dayalbag, maximum $\mathrm{O}_{3}$ concentrations are observed during the summer seasons. The enhanced concentration of $\mathrm{O}_{3}$ in the northern and northeastern parts of India are predominant during the pre-monsoon season. The intrusion of $\mathrm{O}_{3}$ from the free troposphere is the main reason for the increase in $\mathrm{O}_{3}$ concentrations observed at nighttime hours in the mountainous regions. From these analyses, we conclude that the variations of surface $\mathrm{O}_{3}$ at different locations in the Indian sub-continent mainly depend on the latitude/longitude variation, weather parameters, availability of solar radiation, variations in boundary layer height, concentrations of precursor gases, and anthropogenic activities.

Table 6. Observed maxima and minima surface $\mathrm{O}_{3}$ concentrations at Kannur and other locations in India for a comparison.

\begin{tabular}{|c|c|c|c|c|c|}
\hline \multirow{2}{*}{ Locations } & \multirow{2}{*}{ Category } & \multirow{2}{*}{$\begin{array}{c}\text { Period of } \\
\text { Observations }\end{array}$} & \multicolumn{2}{|c|}{ Daytime Observed (ppbv) } & \multirow{2}{*}{ Reference } \\
\hline & & & $\begin{array}{c}\text { Maximum } \\
\text { (Season) }\end{array}$ & $\begin{array}{l}\text { Minimum } \\
\text { (Season) }\end{array}$ & \\
\hline Kannur & Rural & 2013-2018 & $\begin{array}{c}35.47 \pm 10.5 \\
\text { Winter }\end{array}$ & $\begin{array}{c}13.5 \pm 5.6 \\
\text { (Monsoon) }\end{array}$ & Present study \\
\hline Jodhpur & $\begin{array}{l}\text { Semi-Arid, } \\
\text { Urban }\end{array}$ & 2012-2013 & $\begin{array}{c}47 \pm 11.5 \\
\text { Pre monsoon }\end{array}$ & $\begin{array}{c}27 \pm 12 \\
\text { (Monsoon) }\end{array}$ & {$[72]$} \\
\hline Trivandrum & Coastal Site & 2007-2009 & $40 \pm 8.5$, Winter & $\begin{array}{c}18 \pm 5 \\
\text { (Monsoon) }\end{array}$ & [111] \\
\hline Agra & Urban & 2012-2013 & $\begin{array}{c}32.5 \pm 19.3 \\
\text { Summer }\end{array}$ & $\begin{array}{c}8.74 \pm 3.8 \\
\text { (Monsoon) }\end{array}$ & [8] \\
\hline Delhi & Urban & 2012-2013 & $38 \pm 7$, Winter & $\begin{array}{c}28 \pm 6 \\
\text { (Monsoon) }\end{array}$ & [11] \\
\hline NCR Delhi & Urban & 2014-2015 & $\begin{array}{c}45.3 \pm 9.5 \\
\text { Winter }\end{array}$ & $\begin{array}{l}23.8 \pm 10.9 \\
\text { (Monsoon) }\end{array}$ & [25] \\
\hline Udaipur & $\begin{array}{l}\text { Semi-Arid, } \\
\text { Urban }\end{array}$ & 2011-2012 & $\begin{array}{c}46 \pm 12.5, \text { Pre } \\
\text { monsoon }\end{array}$ & $\begin{array}{c}26 \pm 4.6 \\
\text { (Monsoon) }\end{array}$ & [73] \\
\hline Port Blair & Marine Site & 2005-2007 & $30 \pm 5$, Winter & $\begin{array}{c}10 \pm 5 \\
\text { (Monsoon) }\end{array}$ & [119] \\
\hline Kanpur & Urban & 2009-2013 & $\begin{array}{c}27.9 \pm 17.8 \\
\text { Summer }\end{array}$ & $\begin{array}{c}10.5 \pm 5.6 \\
\text { (Monsoon) }\end{array}$ & [120] \\
\hline
\end{tabular}


Table 6. Cont.

\begin{tabular}{|c|c|c|c|c|c|}
\hline \multirow{2}{*}{ Locations } & \multirow{2}{*}{ Category } & \multirow{2}{*}{$\begin{array}{c}\text { Period of } \\
\text { Observations }\end{array}$} & \multicolumn{2}{|c|}{ Daytime Observed (ppbv) } & \multirow{2}{*}{ Reference } \\
\hline & & & $\begin{array}{l}\text { Maximum } \\
\text { (Season) }\end{array}$ & $\begin{array}{c}\text { Minimum } \\
\text { (Season) }\end{array}$ & \\
\hline Anantapur & $\begin{array}{l}\text { Semi-Arid, } \\
\text { Rural }\end{array}$ & 2012-2013 & $\begin{array}{l}64.9 \pm 5.3 \\
\text { Summer }\end{array}$ & $\begin{array}{l}19.9 \pm 1.02 \\
\text { (Monsoon) }\end{array}$ & {$[61]$} \\
\hline Dibrugarh & Sub Himalayan & 2009-2013 & $\begin{array}{c}42.9 \pm 10.3, \text { Pre } \\
\text { monsoon }\end{array}$ & $\begin{array}{c}17.3 \pm 7.0 \\
\text { (Monsoon) }\end{array}$ & [103] \\
\hline Bhubaneswar & Urban & 2009-2011 & $\begin{array}{c}61.7 \pm 12.7 \\
\text { Winter }\end{array}$ & $\begin{array}{l}20.57 \pm 5.8 \\
\text { (Monsoon) }\end{array}$ & [121] \\
\hline Mohal, Kullu & Semi-Urban & 2010-2011 & $\begin{array}{l}84 \pm 23.9, \text { Pre } \\
\text { monsoon }\end{array}$ & $\begin{array}{c}10 \pm 6.5 \\
\text { (Monsoon) }\end{array}$ & [116] \\
\hline Ootty & $\begin{array}{l}\text { High-Altitude } \\
\text { Mountain }\end{array}$ & 2010-2012 & $\begin{array}{l}53.5 \pm 8.2 \\
\text { Winter }\end{array}$ & $\begin{array}{l}19.81 \pm 2.4 \\
\text { (Monsoon) }\end{array}$ & [122] \\
\hline Pantnagar & Semi-Urban & 2009-2011 & $\begin{array}{l}48.7 \pm 13.8 \\
\text { Spring }\end{array}$ & $\begin{array}{l}10.8 \pm 12.1 \\
\text { (Monsoon) }\end{array}$ & [62] \\
\hline Dayalbag & Suburban & 2008-2009 & $60 \pm 10$, Summer & $\begin{array}{c}20 \pm 6 \\
\text { (Monsoon) }\end{array}$ & [117] \\
\hline Nainital & $\begin{array}{l}\text { High Altitude } \\
\text { in Himalaya }\end{array}$ & 2006-2008 & $\begin{array}{l}67.2 \pm 14.2 \\
\text { Late spring }\end{array}$ & $\begin{array}{c}24.9 \pm 8.4 \\
\text { (Monsoon) }\end{array}$ & [14] \\
\hline
\end{tabular}

\section{Conclusions}

This describes a review on the impact of ground-level ozone on air quality changes in the atmosphere of Kannur. This study is based on the observational data from January 2013-December 2018 by employing ground-based gas analyzers. The observations showed a well-marked diurnal cycle of $\mathrm{O}_{3}$ concentration with a minimum during the night-time hours and maximum at noon hours. It is understood that climatic factors can significantly influence the photochemical production and the loss of surface $\mathrm{O}_{3}$. The variation of $\mathrm{O}_{3}$ has been shown to significantly influence the solar radiation, atmospheric temperature, and the concentrations of $\mathrm{NO}_{2}$. The enhancement in the $\mathrm{O}_{3}$ concentration relative to the increase in solar radiation indicates an active photochemical reaction in the presence of solar radiation. On a diurnal and monthly basis, daytime $\mathrm{O}_{3}$ is negatively correlated with the absolute water vapor content in the atmosphere. An artificial neural network study has been conducted to understand how the increase in atmospheric temperature from 2013 to 2018 will impact ozone fluctuations. The neural network analysis revealed that the atmospheric temperature positively affects the productions of $\mathrm{O}_{3}$ over the observational site, and $\mathrm{O}_{3}$ values are consistently enhancing from 2013 to 2018. The enhancement (10.94\%) in $\mathrm{O}_{3}$ from 2013 to 2018 is matched with an enhancement $(4.46 \%)$ in the surface air temperature. Thus, a fairly small variation in temperature can significantly enhance ozone production. The model-simulated output $\mathrm{O}_{3}$ concentrations with the observed concentration shows a positive linear correlation with correlation coefficient $(r=0.89)$. The NCAR-MMP box model study was conducted to validate the variations of $\mathrm{O}_{3}$ in different seasons and years, and the simulations resulted in a validation of the information obtained in the observations. This study reveals that a significant amount of surface $\mathrm{O}_{3}$ is produced from its precursors, even in a location with very little industrial activities.

Author Contributions: Data curation, R.C.T.; Investigation, N.T. and S.K.M.K.; Project administration, S.K.M.K.; Resources, S.K.M.K. and B.M.; Supervision, S.K.M.K. and V.K.T. All authors have read and agreed to the published version of the manuscript.

Funding: This work was funded by Indian Space Research Organization-Geosphere Biosphere Programme (ISRO-GBP) through their Atmospheric Chemistry-Transport and Modelling Project (AT-CTM), for the long term study of surface $\mathrm{O} 3$ and its precursor gases over Kannur. 
Acknowledgments: The authors are grateful to the Indian Space Research Organization, Bangalore for the financial support provided through Atmospheric Chemistry, Transport, and Modeling project of Geosphere Biosphere Programme. The authors wish to thank Shyam Lal, Physical Research Laboratory, Ahmadabad for his constant inspiration and support throughout the programme. The authors are also grateful to R.K Sunil Kumar, Director, School of Information Science and Technology, Kannur University for his support and suggestions to develop the MLP artificial neural network model. Resmi expresses her gratitude to R. Venkatachalam (Principal) and D. Manivannan (HOD of Physics) of Erode Arts and Science College, Tamil Nadu for providing the necessary facilities and constant encouragement. Valsaraj thanks the Charles and Hilda Roddey Distinguished Professorship at LSU which supported the preparation of this review.

Conflicts of Interest: The authors declare no conflict of interest.

\section{References}

1. Cunningham, B.; Cunningham, M.A.; Saigo, B.W. Environmental Science: A Global Concern, 8th ed.; McGraw Hill: Boston, MA, USA, 2005.

2. Ambient Air Pollution: A Global Assessment of Exposure and Burden of Disease: Geneva; World Health Organization (WHO) Library Cataloguing in Publication Data: Geneva, Switzerland, 2016.

3. Kalpana, B.; Sagnik, D.; Tarun, G.; Dhaliwal, R.; Michael, B.; Aaron, J.; Jeffrey, D.; Gufran, B.; Tushar, K.J.; Ashutosh, N.A.; et al. The impact of air pollution on deaths, disease burden, and life expectancy across the states of India. Lancet Planet Health 2019, 3, 26-39.

4. Debaje, S.B.; Kakade, A.D.; Jeyakumar, S.J. Air pollution effect of $\mathrm{O}_{3}$ on crop yield in rural India. J. Hazard. Mater. 2010, 183, 773-779. [CrossRef] [PubMed]

5. Teixeira, E.; Fischer, G.; Velthuizen, H.V.; Dingenen, R.V.; Dentener, F.; Mills, G.; Walter, C.; Ewert, F. Limited potential of crop management for mitigating surface ozone impacts on global food supply. Atmos. Environ. 2011, 45, 2569-2576. [CrossRef]

6. Wang, Y.; Hu, B.; Tang, G.; Ji, D.; Zhang, H.; Bai, J.; Wang, X.; Wang, Y. Characteristics of ozone and its precursors in Northern China: A comparative study of three sites. Atmos. Res. 2013, 132, 450-459. [CrossRef]

7. Mabahwi, N.A.B.; Leh, O.L.H.; Omar, D. Human Health and Wellbeing: Human health effect of air pollution. Procedia-Soc. Behav. Sci. 2014, 153, 221-229. [CrossRef]

8. Saini, R.; Taneja, A.; Singh, P. Surface ozone scenario and air quality in the north-central part of India. J. Environ. Sci. 2017, 59, 72-79. [CrossRef]

9. Nevers, N.D. Air Pollution Control Engineering Seconded; McGraw-Hill Companies, Inc.: New York, NY, USA, 2000; pp. 571-573.

10. Monks, P.S.; Archibald, A.T.; Colette, A.; Cooper, O.; Coyle, M.; Derwent, R.; Fowler, D.; Granier, C.; Law, K.S.; Mills, G.; et al. Tropospheric ozone and its precursors from the urban to the global scale from air quality to short-lived climate forcer. Atmos. Chem. Phys. 2015, 15, 8889-8973. [CrossRef]

11. Sharma, A.; Sharma, S.K.; Mandal, T.K.R. Influence of ozone precursors and particulate matter on the variation of surface ozone at an urban site of Delhi India. Sustain. Environ. Res. 2016, 26, 76-83. [CrossRef]

12. Volz, A.; Kley, D. Evaluation of the Montsouris series of ozone measurements made in the nineteenth century. Nature 1998, 332, 240-242. [CrossRef]

13. Bonasoni, P.; Stohl, A.; Cristofanaelly, P.; Calzolari, F.; Colombo, T.; Evangelisti, F. Background ozone variations at Mt Cimone Station. Atmos. Environ. 2000, 34, 5183-5189. [CrossRef]

14. Kumar, R.; Naja, M.; Venkataramani, S.; Wild, O. Variations in surface ozone at Naintail a high altitude site in the central Himalayas. J. Geophys. Res. 2010, 115, D16302. [CrossRef]

15. David, L.M.; Nair, P.R. Tropospheric column $\mathrm{O}_{3}$ and $\mathrm{NO}_{2}$ over the Indian region observed by Ozone Monitoring Instrument (OMI): Seasonal changes and long term trends. Atmos. Environ. 2013, 65, 25-39. [CrossRef]

16. Tiwari, S.; Srivastava, A.K.; Bisht, D.S.; Parmita, P.; Srivastava, M.K.; Attri, S.D. Diurnal and seasonal variations of black carbon and $\mathrm{PM}_{25}$ over New Delhi India: Influence of meteorology. Atmos. Res. 2013, 125, 50-62. [CrossRef]

17. Ojha, N.; Naja, M.; Sarangi, T.; Kumar, R.; Bhardwaj, P.; Lal, S.; Venkataramani, S.; Sagar, R.; Kumar, A.; Chandola, H.C. On the processes influencing the vertical distribution of ozone over the central Himalayas: Analysis of yearlong ozonesonde observations. Atmos. Environ. 2014, 88, 201-211. [CrossRef] 
18. Thompson, M.L.; Reynolds, J.; Cox, L.H.; Guttorp, P.; Sampson, P.D. A review of statistical methods for the meteorological adjustment of tropospheric ozone. Atmos. Environ. 2001, 35, 617-630. [CrossRef]

19. Srivastava, S.; Lal, S.; Naja, M.; Venkataramani, S.; Gupta, S. Influence of regional pollution and long range transport over Western India: Analysis of ozonesonde data. Atmos. Environ. 2012, 47, 174-182. [CrossRef]

20. Mahapatra, P.S.; Panda, S.; Das, N.; Rath, S.; Das, T. Variation in black carbon mass concentration over an urban site in the eastern coastal plains of the Indian sub-continent. Theor. Appl. Clim. 2013, 117, 133-147. [CrossRef]

21. Cassandra, V.H.; Munger, J.W.; Steven, C.W.; Zahniser, M.; Nelson, D.J.; McManus, B. Atmospheric reactive nitrogen concentration and flux budgets at a North eastern US forest site. Agric. For. Meteorol. 2006, 136, 159-174.

22. Penga, Y.P.; Chena, K.S.; Laib, C.H.; Lua, P.J.; Kaoa, J.H. Concentrations of $\mathrm{H}_{2} \mathrm{O}_{2}$ and $\mathrm{HNO}_{3}$ and $\mathrm{O}_{3}-$ VOCs-NOx sensitivity in ambient air in southern Taiwan. Atmos. Environ. 2006, 40, 6741-6751. [CrossRef]

23. Raivonen, M.; Vesala, T.; Pirjola, L.; Altimir, N.; Keronen, P.; Kulmala, M.; Hari, P. Compensation point of NOx exchange: Net result of NOx consumption and production. Agric. For. Meteorol. 2009, 149, 1073-1081. [CrossRef]

24. Swamy, Y.V.; Venkanna, R.; Nikhil1, G.N.; Chitanya, D.N.S.K.; Sinha, P.R.; Ramakrishna, M.; Rao, A.G. Impact of oxides of nitrogen volatile organic carbons and black carbon emissions on ozone weekend/weekday variations at a semiarid urban site in Hyderabad. Aerosol Air Qual. Res. 2012. [CrossRef]

25. Tyagi, S.; Tiwari, S.; Mishra, A.; Hopke, P.K.; Attri, S.D.; Srivastava, A.K.; Bisht, D.S. Spatial variability of concentrations of gaseous pollutants across the national capital region of Delhi India. Atmos. Pollut. Res. 2016. [CrossRef]

26. Kunhikrishnan, T.; Lawrence, M.G.; Kuhlmann, R.V.; Wenig, M.O.; Willem, A.; Asman, H.; Richter, A.; Burrows, J.P. Regional NOx emission strength for the Indian subcontinent and the impact of emissions from India and neigh boring countries on regional $\mathrm{O}_{3}$ chemistry. J. Geophys. Res. 2006, 109, D15301. [CrossRef]

27. Van der A, R.J.; Eskes, H.J.; Boersma, K.F.; Van Noije, T.P.C.; Roozendael, V.M.; DeSmedt, I.; Peters, D.H.M.U.; Meijer, E.W. Trends seasonal variability and dominant NOx source derived from a ten-year record of $\mathrm{NO}_{2}$ measured from space. J. Geophys. Res. 2008, 113, D04302. [CrossRef]

28. Rai, R.; Rajput, M.; Agrawal, M.; Agrawal, S.B. Gaseous air pollutants: A review on current and future trends of emissions and impact on agriculture. J. Sci. Res. 2011, 55, 77-102.

29. Comrie, A.C.; Yarnal, B. Relationships between synoptic scale atmospheric circulation and ozone concentrations in metropolitan Pittsburgh Pennsylvania. Atmos. Environ. 1992, 26, 301-312. [CrossRef]

30. Zhang, J.; Rao, S.T.; Daggupaty, S.M. Meteorological processes and ozone exceedances in the north-eastern United States during the 12-16 July 1995 episode. J. Appl. Meteorol. 1998, 37, 776-789. [CrossRef]

31. Dueñas, C.; Fern'andez, M.C.; Caete, S.; Carretero, J.; Liger, E. Assessment of ozone variations and meteorological effects in an urban area in the Mediterranean Coast. Sci. Total Environ. 2002, 299, 97-113. [CrossRef]

32. Camalier, L.; Cox, W.; Dolwick, P. The effects of meteorology on ozone in urban areas and their use in assessing ozone trends. Atmos. Environ. 2007, 41, 7127-7137. [CrossRef]

33. Bloomfield, P.; Royle, J.A.; Steinberg, L.J.; Yang, Q. Accounting for meteorological effects in measuring urban ozone levels and trends. Atmos. Environ. 1996, 30, 3067-3077. [CrossRef]

34. Olszyna, K.J.; Luria, M.; Meagher, J.F. The correlation of temperature and rural ozone levels in south-eastern USA. Atmos. Environ. 1997, 31, 3011-3022. [CrossRef]

35. C'ardenas, L.M.; Austin, J.F.; Burgess, R.A. Correlations between $\mathrm{CO}, \mathrm{NOy}, \mathrm{O}_{3}$ and non-methane hydrocarbons and their relationships with meteorology during winter 1993 on the North Norfolk Coast UK. Atmos. Environ. 1998, 32, 3339-3351. [CrossRef]

36. Tu, J.; Xia, Z.G.; Wang, H.; Li, W. Temporal variations in surface ozone and its precursors and meteorological effects at an urban site in China. Atmos. Res. 2007, 85, 310-337. [CrossRef]

37. Patil, S.D.; Thompson, B.; Revadekar, J.V. On the variation of the tropospheric ozone over Indian region in relation to the meteorological parameters International. J. Remote Sens. 2009, 30, 2813-2826. [CrossRef]

38. Khiem, M.; Ooka, R.; Huang, H.; Hayami, H.; Yoshikado, Y.; Kawamoto, Y. Analysis of the relationship between changes in meteorological conditions and the variation in summer Ozone Levels over the Central Kanto Area. Adv. Meteorol. 2010, 2010, 349248. [CrossRef] 
39. Aneja, V.P.; Businger, S.; Li, Z.; Ciaiborn, C.S.; Murthy, A. Ozone climatology at high elevations in the southern Appalachians. J. Geophys. Res. 1991, 96, 1007-1021. [CrossRef]

40. Kourtidis, K.; Zerefos, C.; Rapsomanikis, S.; Simeonov, V.; Balis, D.; Perros, P.E. Regional levels of $\mathrm{O}_{3}$ in the troposphere over eastern Mediterranean. J. Geophys. Res. 2002, 107, 8140. [CrossRef]

41. Zerefos, C.; Kourtidis, K.A.; Melas, D.; Balis, D.; Zanis, P.; Katsaros, L.; Mantis, H.T.; Repapis, C.; Isaksen, I.; Sundet, J.; et al. Photochemical activity and solar ultraviolet radiation modulation factors (PAUR): An overview of the project. J. Geophys. Res. 2002, 107, 8134. [CrossRef]

42. Qin, Y.; Tonnesen, G.S.; Wang, Z. One-hour and eight-hour average $\mathrm{O}_{3}$ in the California south coast air quality management district: Trends in peak values and sensitivity to precursors. Atmos. Environ. 2004, 38, 2197-2207. [CrossRef]

43. Mazzeo, A.N.; Venegas, E.L.; Choren, H. Analysis of $\mathrm{NO} \mathrm{NO}_{2} \mathrm{O}_{3}$ and $\mathrm{NOx}$ concentrations measured at a green area of Buenos Aires City during wintertime. Atmos. Environ. 2005, 39, 3055-3068. [CrossRef]

44. Bossioli, E.; Tombrou, M.; Dandou, A.; Soulakellis, N. Simulation of the effects of critical factors on $\mathrm{O}_{3}$ formation and accumulation in the greater Athens area. J. Geophys. Res. 2007, 112, D02309. [CrossRef]

45. Ordóñez, C.; Brunner, D.; Staehelin, J.; Hadjinicolaou, P.; Pyle, J.A.; Jonas, M.; Wernli, H.; Prevot, A.S.H. Strong influence of lowermost stratospheric ozone on lower tropospheric background ozone changes over Europe. Geophys. Res. Lett. 2007, 34, L07805. [CrossRef]

46. Alvarez, R.; Weilenmann, M.; Favez, J.Y. Evidence of increased mass fraction of $\mathrm{NO}_{2}$ within real world NOx emissions of modern light vehicles derived from a reliable online measuring method. Atmos. Environ. 2008, 42, 4699-4707. [CrossRef]

47. Shan, W.; Yin, Y.; Zhang, J.; Ji, X.; Deng, X. Surface ozone and meteorological condition in a single year at an urban site in central-eastern China. Environ. Monit. Assess. 2009, 151, 127-141. [CrossRef]

48. Solberg, S.; HovØSovde, A.; Isaksen, I.S.A.; Coddeville, P.; De Backer, H.; Forster, C.; Orsolini, Y.; Uhse, K. European surface ozone in the extreme summer 2003. J. Geophys. Res. 2008, 113, D07307. [CrossRef]

49. Yarwood, N.G.; Grant, J.; Koo, B.; Dunker, A.M. Modeling weekday to weekend changes in emissions and $\mathrm{O}_{3}$ in the Los Angeles basin for 1997 and 2010. Atmos. Environ. 2008, 42, 3765-3779. [CrossRef]

50. Yin, Y.; Shan, W.; Ji, X.; Deng, X.; Cheng, J.; Li, L. Analysis of the surface ozone during summer and autumn at a coastal site in East China. Bull. Environ. Contam. Toxicol. 2010, 85, 10-14. [CrossRef]

51. Song, F.; Shin, J.Y.; Atresino, R.J.; Gao, Y. Relationships among the spring time ground-level $\mathrm{NOx}_{3}$ and $\mathrm{NO}_{3}$ in the vicinity of highways in the US East Coast. Atmos. Pollut. Res. 2011, 2, 374-383. [CrossRef]

52. Wallace, H.W.; Jobson, B.T.; Erickson, M.H.; McCoskey, J.K.; VanReken, T.M.; Lamb, B.K.; Vaughan, J.K.; Hardy, R.J.; Cole, J.L.; Strachan, S.M.; et al. Comparison of wintertime CO to NOx ratios to MOVES and MOBILE62 on-road emissions inventories. Atmos. Environ. 2012, 63, 289-297. [CrossRef]

53. Henschel, S.; Querol, X.; Atkinson, R.; Pandolfi, M.; Zeka, A.; Tertre, A.; Analitis, A.; Katsouyanni, K.; Chanel, O.; Pascal, M.; et al. Ambient air $\mathrm{SO}_{2}$ patterns in 6 European cities. Atmos. Environ. 2013, 79, $236-247$. [CrossRef]

54. Han, S.; Zhang, M.; Zhao, C.; Lu, X.; Ran, L.; Han, M.; Li, P.; Li, X. Differences in ozone photochemical characteristics between the megacity Tianjin and its rural surroundings. Atmos. Environ. 2013, 79, $209-216$. [CrossRef]

55. Sun, Y.; Zhou, X.; Wai, K.; Yuan, Q.; Xu, Z.; Zhou, S.; Qi, Q.; Wang, W. Simultaneous measurement of particulate and gaseous pollutants in an urban city in North China Plain during the heating period: Implication of source contribution. Atmos. Res. 2013, 134, 24-34. [CrossRef]

56. Lurmann, F.W.; Wexler, A.S.; Pandis, S.N.; Mussara, S.; Kumar, N.; Seinfeld, J.H. Modelling Urban and Regional Aerosols-II Application to California's South Coast Air Basin. Atmos. Environ. 1997, 31, 2695-2715. [CrossRef]

57. Pai, P.; Vijayaraghavan, K.; Seigneur, C. Particulate matter modeling in the Los Angeles basin using the SAQM-AERO. J. Air Waste Manag. Assoc. 2000, 50, 32-42. [CrossRef]

58. Lazaridis, M.; Spyridaki, A.; Solberg, S.; Smolik, J.; Zdimal, V.; Eleftheriadis, K. Mesoscale modeling of combined aerosol and photo-oxidant processes in the Eastern Mediterranean. Atmos. Chem. Phys. 2005, 5, 927-940. [CrossRef]

59. Resmi, C.T.; Nishanth, T.; Kumar, M.K.S.; Balachandramohan, M.; Valsaraj, K.T. Temporal changes in air quality during a festival season in Kannur India. Atmosphere 2019, 10, 137. [CrossRef] 
60. Lingaswamy, A.P.; Arafath, S.M.; Balakrishnaiah, G.; Rama Gopal, K.; Reddy, N.S.K.; Reddy, K.R.O.; Reddy, R.R.; Rao, T.C. Observations of trace gases photolysis rate coefficients and model simulations over semi-arid region India. Atmos. Environ. 2017, 158, 246-258. [CrossRef]

61. Rama Gopal, K.; Lingaswamy, A.P.; Arafath, S.M.D.; Balakrishnaiah, G.; Pavan, K.S.; Devi, U.K.; Reddy, N.S.K.; Reddy, K.R.O.; Reddy, R.R.; Lal, S. Seasonal heterogeneity in ozone and its precursors (NOx) by in-situ and model observations on semi-arid station in Anantapur (AP). Atmos. Environ. 2014, 84, 294-306. [CrossRef]

62. Ojha, N.; Naja, M.; Singh, K.P.; Sarangi, T.; Kumar, R.; Lal, S.; Lawrence, M.G.; Butler, T.M. Variabilities in $\mathrm{O}_{3}$ at a semi-urban site in the Indo-Gangetic Plain region: Association with the meteorology and regional processes. J. Geophys. Res. 2012, 117, D20301. [CrossRef]

63. Nair, P.R.; David, L.M.; Girach, I.A.; George, S.K. Ozone in the marine boundary layer of Bay of Bengal during post-winter period: Spatial pattern and role of meteorology. Atmos. Environ. 2011, 45, 4671-4681. [CrossRef]

64. Girach, I.A.; Nair, P.R.; David, L.M.; Hegde, P.; Mishra, M.K.; Kumar, M.G.; Das, M.S.; Ojha, N.; Naja, M. The changes in near-surface ozone and precursors at two nearby tropical sites during annular solar eclipse of 15 January 2010. J. Geophys. Res. 2012, 117, D01303. [CrossRef]

65. Nishanth, T.; Praseed, K.M.; Kumar, M.K.S.; Valsaraj, K.T. Influence of ozone precursors and $\mathrm{PM}_{10}$ on the variation of surface $\mathrm{O}_{3}$ over Kannur India. Atmos. Res. 2014, 138, 112-124. [CrossRef]

66. Shan, W.; Yin, Y.; Zhang, J.; Ding, Y. Observational study of surface $\mathrm{O}_{3}$ at an urban site in East China. Atmos. Res. 2008, 89, 252-261. [CrossRef]

67. Chakraborty, K.; Mehrotra, K.; Mohan, C.K.; Ranka, S. Forecasting the behavior of multivariate time series using neural networks. Neural Netw. 1992, 5, 961-970. [CrossRef]

68. Narasimhan, R.; Keller, J.; Subramaniam, G. Ozone modelling using neural networks. J. Appl. Meteorol. 2000, 39, 291-296. [CrossRef]

69. Faris, H.; Alkasassbeh, M.; Rodan, A. Artificial Neural Networks for Surface Ozone Prediction: Models and Analysis. Pol. J. Environ. Stud. 2014, 23, 341-348.

70. Kleinman, L.; Lee, Y.N.; Springston, S.R.; Nunnermacker, L.; Zhou, X.; Brown, R.; Hallock, K.; Klotz, P.; Leahy, D.; Lee, J.H.; et al. Ozone formation at a rural site in the southern United States. J. Geophys. Res. 1994, 99, 3469-3482. [CrossRef]

71. Kneizys, F.X.; Shettle, E.P.; Gallery, W.O.; Chetwynd, J.H., Jr.; Abreu, L.W.; Selby, J.E.A.; Fenn, R.W.; McClatchey, R.A. Atmospheric Transmittance/radiance: Computer code LOWTRAN 5; AFGLTR-80-0067 AD088215; Optical Physics Division, Air Force Geophysics Laboratory: Wright-Patterson Air Force Base, OH, USA, 1980.

72. Pancholi, P.; Kumar, A.; Bikundia, D.S.; Chourasiya, S. An observation of seasonal and diurnal behavior of $\mathrm{O}_{3}$-NOx relationships and local/regional oxidant $\left(\mathrm{OX}=\mathrm{O}_{3}+\mathrm{NO}_{2}\right)$ levels at a semi-arid urban site of western India. Sustain. Environ. Res. 2018, 28, 79-89. [CrossRef]

73. Yadav, R.; Sahu, L.K.; Beig, G.; Jaaffrey, S.N.A. Role of long-range transport and local meteorology in seasonal variation of surface ozone and its precursors at an urban site of India. Atmos. Res. 2016. [CrossRef]

74. Li, J.; Wang, Z.; Wang, X.; Yamaji, K.; Takigawa, M.; Kanaya, Y.; Pochanart, P.; Liu, Y.; Irie, H.; Hu, B.; et al. Impacts of aerosols on summertime tropospheric photolysis frequencies and photochemistry over Central Eastern China. Atmos. Environ. 2011, 45, 1817-1829. [CrossRef]

75. Bian, H.; Han, S.Q.; Tie, X.X.; Sun, M.L.; Liu, A.X. Evidence of impact of aerosols on surface ozone concentration in Tianjin China. Atmos. Environ. 2007, 41, 4672-4681. [CrossRef]

76. Reddy, B.S.K.; Kumar, K.R.; Balakrishnaiah, G.; Gopal, K.R.; Reddy, R.R.; Sivakumar, V.; Lingaswamy, A.P.; Arafath, S.M.; Umadevi, K.; Pavan, K.S.; et al. Analysis of diurnal and seasonal behavior of surface ozone and its precursors (NOx) at a semi-arid rural site in Southern India. Aerosol Air Qual. Res. 2012, 12, 1081-1094. [CrossRef]

77. Evans, S.J.; Toumi, R.; Harries, J.E.; Chipperfield, M.P.; Russel, J.M. Trends in stratospheric humidity and the sensitivity of ozone to these trends. J. Geophys. Res. 1998, 103, 8715-8725. [CrossRef]

78. Kirk Davidoff, D.B.; Hintsa, E.J.; Anderson, G.; Keith, D.W. The effect of climate change of ozone depeletion through changes in stratospheric water vapour. Nature 1999, 402, 399-401. [CrossRef]

79. Foster, P.M.; De, F.; Shine, K.P. Assessing the climate impact of trend in stratospheric water vapour. Geophys. Res. Lett. 2002, 29. [CrossRef]

80. Lu, X.; Zhang, L.; Shen, L. Meteorology and Climate Influences on Tropospheric Ozone: A Review of Natural Sources Chemistry and Transport Patterns. Curr. Pollut. Rep. 2019, 1-23. [CrossRef] 
81. Pyrgou, A.; Hadjinicolaou, P.; Santamouris, M. Enhanced near-surface ozone under heat wave conditions in a Mediterranean island. Nature 2018, 8, 9191. [CrossRef]

82. Buhr, M.P.; Hsu, K.J.; Liu, C.M.; Liu, R.; Wei, L.; Liu, Y.C.; Kuo, S. Trace gas measurements and air mass classification from a ground station in Taiwan during the PEM-WEST experiment. J. Geophys. Res. 1995, 101, 2025-2035. [CrossRef]

83. Sillman, S.; Samson, P.J. Impact of temperature on oxidant photochemistry in urban polluted rural and remote environments. J. Geophys. Res. 1995, 100, 11497-11508. [CrossRef]

84. Steiner, A.L.; Tonse, S.; Cohen, R.C.; Goldstein, A.H.; Harley, R. Influence of future climate and emissions on regional air quality in California. J. Geophys. Res. 2006, 111, D18303. [CrossRef]

85. Stathopoulou, E.; Mihalakakou, G.; Santamouris, M.; Bagiorgas, H.S. On the impact of temperature on tropospheric Ozone concentration levels in urban environments. J. Earth Syst. Sci. 2008, 117, 227-236. [CrossRef]

86. De Miguel, A.; Mateos, D.; Bilbao, J.; Román, R. Sensitivity analysis of ratio between ultraviolet and total shortwave solar radiation to cloudiness ozone aerosols and precipitable water. Atmos. Res. 2011, 102, 136-144. [CrossRef]

87. Kleanthous, S.; Vrekoussis, M.; Mihalopoulos, N.; Kalabokas, P.; Lelieveld, J. On the temporal and spatial variation of ozone in Cyprus. Sci. Total Environ. 2014, 476, 677-687. [CrossRef] [PubMed]

88. Lee, Y.C.; Shindell, D.T.; Faluvegi, G.; Wenig, M.; Lam, Y.F.; Ning, Z.; Hao, S.; Lai, C.S. Increase of ozone concentrations its temperature sensitivity and the precursor factor in South China. Tellus B 2014, 66, 23455. [CrossRef]

89. Pusede, S.E.; Steiner, A.L.; Cohen, R.C. Temperature and recent trends in the chemistry of continental surface ozone. Chem. Rev. 2015, 115, 3898-3918. [CrossRef]

90. Coates, J.; Mar, K.A.; Ojha, N.; Butler, T.M. The influence of temperature on ozone production under varying NOx conditions-A modelling study. Atmos. Chem. Phys. 2016, 16, 11601-11615. [CrossRef]

91. Porter, W.C.; Heald, C.L. The mechanisms and meteorological drivers of the ozone temperature relationship. Atmos. Chem. Phys. Discuss. 2019. [CrossRef]

92. Dawson, J.P.; Adams, P.J.; Pandis, S.N. Sensitivity of ozone to summertime climate in the eastern USA: A modeling case study. Atmos. Environ. 2007, 41, 1494-1511. [CrossRef]

93. Wu, S.; Mickley, L.J.; Leibensperger, E.M.; Jacob, D.J.; Rind, D.; Streets, D.G. Effects of 2000-2050 global change on ozone air quality in the United States. J. Geophys. Res. 2008, 113. [CrossRef]

94. Mckendry, I.G. Synoptic circulation and summer time ground level ozone concentrations at Vancouver British Colombia. J. Appl. Metrol. 1994, 33, 627-641. [CrossRef]

95. Kumar, R.; Barth, M.C.; Pfister, G.G.; Monache, L.D.; Lamarque, J.F.; Nicholls, A.S.; Tilmes, S.; Ghude, S.D.; Wiedinmyer, C.; Naja, M.; et al. How Will Air Quality Change in South Asia by 2050? J. Geophys. Res. 2018, 123, 1840-1864. [CrossRef]

96. Yamaji, K.; Ohara, T.; Uno, I.; Kurokawa, J.; Pochanart, P.; Akimoto, H. Future prediction of surface ozone over east Asia using models-3 community multiscale air quality modeling system and regional emission inventory in Asia. J. Geophys. Res. 2008, 113, D08306. [CrossRef]

97. Barnard, J.C.; Chapman, E.G.; Fast, J.D.; Schmelzer, J.R.; Slusser, J.R.; Shetter, R.E. An evaluation of the FAST-J photolysis algorithm for predicting nitrogen dioxide photolysis rates under clear and cloudy conditions. Atmos. Environ. 2004, 38, 3393-3403. [CrossRef]

98. Gustavo, G.P.; Rafael, P.F.; Beatriz, M.T. Photolysis rate coefficients calculations from broadband UV-B irradiance: Model-measurement interaction. Atmos. Environ. 2005, 39, 857-866.

99. Aumont, B.; Madronich, S.; Bey, I.; Tyndall, G.S. Contribution of secondary VOC to the composition of aqueous atmospheric particles: A modelling approach. J. Atmos. Chem. 2000, 35, 59-75. [CrossRef]

100. Madronich, S. Chemical evolution of gaseous air pollutants down-wind of tropical megacities: Mexico City case study. Atmos. Environ. 2006, 40, 6012-6018. [CrossRef]

101. Ahammed, Y.N.; Reddy, R.R.; Gopal, K.R. Seasonal variation of the surface ozone and its precursor gases during 2001- 2003, measured at Anantapur (14.62N), a semi-arid site in India. Atmos. Res. 2006, 80, 151-164. [CrossRef]

102. Beig, G.; Gunthe, S.; Jadhav, D.B. Simultaneous measurements of ozone and its precursors on a diurnal scale at a semi urban site in India. J. Atmos. Chem. 2007, 57, 239-253. [CrossRef] 
103. Bhuyan, P.K.; Bharali, C.; Pathak, B.; Kalita, G. The role of precursor gases and meteorology on temporal evolution of $\mathrm{O}_{3}$ at a tropical location in northeast India. Environ. Sci. Pollut. Res. 2014, 21, 6696-6713. [CrossRef]

104. Datta, A.; Saud, T.; Goel, A.; Tiwari, S.; Sharma, S.K.; Saxena, M.; Mandal, T.K. Variation of ambient $\mathrm{SO}_{2}$ over Delhi. J. Atmos. Chem. 2011, 65, 127-143. [CrossRef]

105. Debaje, S.B.; Kakade, A.D. Surface $\mathrm{O}_{3}$ variability over western Maharashtra, India. J. Hazard. Mater. 2009, 161, 686-700. [CrossRef] [PubMed]

106. Debaje, S.; Jeyakumar, S.J. High $\mathrm{O}_{3}$ at coastal sites in India. Int. J. Remote Sens. 2011, 32, 993-1015. [CrossRef]

107. Ghude, D.; Jain, S.L.; Arya, B.C.; Beig, G.; Ahammed, Y.N.; Kumar, A.; Tyagi, B. O 3 in ambient air at a tropical megacity, Delhi: Characteristics, trends and cumulative $\mathrm{O}_{3}$ exposure indices. J. Atmos. Chem. 2008, 60, 237-252. [CrossRef]

108. Jain, S.L.; Arya, B.C.; Kumar, A.; Ghude, S.D.; Kulkarni, P.S. Observational study of surface $\mathrm{O}_{3}$ at New Delhi, India. Int. J. Remote Sens. 2005, 26, 3515-3524. [CrossRef]

109. Lal, S.; Naja, M.; Subbaraya, B.H. Seasonal variations in surface ozone and its precursors over an urban site in India. Atmos. Environ. 2000, 34, 2713-2724. [CrossRef]

110. Lal, S.; Sahu, L.K.; Gupta, S.; Srivastava, S.; Modh, K.S.; Venkataramani, S.; Rajesh, T.A. Emission characteristic of $\mathrm{O}_{3}$ related trace gases at a semi-urban site in the Indo-Gangetic plain using intercorrelations. J. Atmos. Chem. 2008, 60, 189-204. [CrossRef]

111. Nair, P.R.; Ajayakumar, R.S.; David, L.M.; Girach, I.A.; Mottungan, K. Decadal changes in surface ozone at the tropical station Thiruvananthapuram $\left(8.542^{\circ} \mathrm{N}, 76.858^{\circ} \mathrm{E}\right)$, India: Effects of anthropogenic activities and meteorological variability. Environ. Sci. Pollut. Res. 2018, 25, 14827-14843. [CrossRef]

112. Naja, M.; Lal, S.; Chand, D. Diurnal and seasonal variabilities in surface $\mathrm{O}_{3}$ at ahigh altitude site Mt Abu (24.60 N, 72.70 E, $1680 \mathrm{~m}$ asl) in India. Atmos. Environ. 2003, 37, 4205-4215. [CrossRef]

113. Nishanth, T.; Praseed, K.M.; Satheesh Kumar, M.K.; Valsaraj, K.T. Observational study of surface $\mathrm{O}_{3}, \mathrm{NOx}_{\text {, }}$ $\mathrm{CH}_{4}$ and total NMHC's at Kannur, India. Aerosol Air Qual. Res. 2014, 14, 1074-1088. [CrossRef]

114. Pulikesi, M.; Baskaralingam, P.; Rayudu, V.N.; Elango, D.; Ramamurthi, V.; Sivanesan, S. Surface $\mathrm{O}_{3}$ measurements at urban coastal site Chennai, in India. J. Hazard. Mater. 2006, 137, 1554-1559. [CrossRef]

115. Purkait, N.N.; De, S.; Sen, S.; Chakrabarty, D.K. Surface $\mathrm{O}_{3}$ and its precursors at two sites in the north east coast of India. Indian. J. Radio Space Phys. 2009, 38, 86-97.

116. Sharma, P.; Kuniyal, J.C.; Chand, K.; Guleria, R.P.; Dhyani, P.P.; Chauhan, C. Surface $\mathrm{O}_{3}$ concentration and its behaviour with aerosols in the north western Himalaya, India. Atmos. Environ. 2013, 71, 44-53. [CrossRef]

117. Singla, V.; Satsangi, A.; Pachauri, T.; Lakhani, A.; Kumari, K.M. $\mathrm{O}_{3}$ formation and destruction at a sub-urban site in North Central region of India. Atmos. Res. 2011, 101, 373-385. [CrossRef]

118. Tiwari, S.; Rai, R.; Agrawal, M. Annual and seasonal variations in tropospheric $\mathrm{O}_{3}$ concentrations around Varanasi. Int. J. Remote Sens. 2008, 29, 4499-4514. [CrossRef]

119. Mandal, T.K.; Peshin, S.K.; Sharma, C.; Gupta, P.K.; Raj, R.; Sharma, S.K. Study of surface ozone at Port Blair, India, a remote marine station in the Bay of Bengal. J. Atmos. Solar-Terr. Phys. 2015, 129, 142-152. [CrossRef]

120. Gaur, A.; Tripathi, S.N.; Kanawade, V.P.; Tare, V.; Shukla, S.P. Four-year measurements of trace gases $\left(\mathrm{SO}_{2}\right.$, $\mathrm{NOx}, \mathrm{CO}$, and $\mathrm{O}_{3}$ ) at an urban location, Kanpur, in Northern India. J. Atmos. Chem. 2014, 71, $283-301$. [CrossRef]

121. Mahapatra, P.S.; Panda, S.; Walvekar, P.P.; Kumar, R.; Das, T.; Gurjar, B.R. Seasonal trends, meteorological impacts, and associated health risks with atmospheric concentrations of gaseous pollutants at an Indian coastal city. Environ. Sci. Pollut. Res. 2014. [CrossRef]

122. Udayasoorian, C.; Jayabalakrishnan, R.M.; Suguna, A.R.; Venkataramani, S.; Lal, S. Diurnal and seasonal characteristics of ozone and NOx over a high altitude Western Ghats location in Southern India. Adv. Appl. Sci. Res. 2013, 4, 309-320.

(C) 2020 by the authors. Licensee MDPI, Basel, Switzerland. This article is an open access article distributed under the terms and conditions of the Creative Commons Attribution (CC BY) license (http://creativecommons.org/licenses/by/4.0/). 